\title{
Shallow seismogenic zone detected from an offshore-onshore temporary seismic network in the Esmeraldas area (northern Ecuador)
}

\section{B. Pontoise}

UMR Géosciences Azur/IRD, IRD-LGTE Case 119, University of Paris et M. CURIE, 4, place Jussieu, 75252 Paris, France (pontoise@ccr.jussieu.fr)

\section{T. Monfret \\ UMR Géosciences Azur/IRD, 250 rue Albert EINSTEIN, Sophia-Antipolis, 06560 Valbonne, France (monfret@geoazur.unice.fr)}

[1] For a given site, many factors control the seismic risk. Earthquake magnitude, hypocentral distance, rupture mechanism, site effects and site vulnerability are among the most important. This article deals with one of these factors: the depth of the seismogenic zone, in the northern Ecuadorian subduction system, beneath a highly vulnerable site, the city of Esmeraldas and its industrial complex, the Ecuadorian oil refinery and shipping terminal. To address this problem, we analyzed data from a three weeks passive seismological experiment, conducted in the spring of 1998, using 13 Ocean Bottom Seismometers and 10 portable land-stations. A preliminary interpretation of wide-angle data obtained in the fall of 2000, in the Manta area, $100 \mathrm{~km}$ South of the study area, unambiguously indicates the presence of a velocity inversion in the Ecuadorian margin velocity structure. This velocity inversion is characterized by a shadow-zone of $\sim 1 \mathrm{~s}$ on the record-sections, and is interpreted as the result of a velocity contrast between the upper plate structure and the sedimentary and basaltic layer II of the subducted oceanic Nazca plate. One-dimensional velocity models are deduced from these wide-angle data and are used for earthquake location in the Esmeraldas area. This highly improved the hypocentral parameter determinations. The updip limit of the seismogenic zone is found at a depth of $\sim 12 \mathrm{~km}, 35 \mathrm{~km}$ eastward of the trench, and the depth of the seismogenic zone below the Esmeraldas city is found at $\sim 20 \mathrm{~km}$. This shallow depth of the seismogenic zone dramatically increases the seismic hazard of the area.

Components: 7926 words, 17 figures, 1 table.

Keywords: Seismogenic zone; seismic hazard; ocean bottom seismometers.

Index Terms: 7223 Seismology: Seismic hazard assessment and prediction; 7230 Seismology: Seismicity and seismotectonics; 7294 Seismology: Instruments and techniques.

Received 27 March 2003; Revised 17 November 2003; Accepted 4 December 2003; Published 26 February 2004.

Pontoise, B., and T. Monfret (2004), Shallow seismogenic zone detected from an offshore-onshore temporary seismic network in the Esmeraldas area (northern Ecuador), Geochem. Geophys. Geosyst., 5, Q02009, doi:10.1029/2003GC000561. 


\section{Introduction and Background}

[2] The subduction in northern Ecuador (Figure 1) is characterized by a rapidly $8 \mathrm{~cm} / \mathrm{y}$ converging oceanic Nazca plate, which underthrusts the overriding South American plate. This subduction zone generates large thrust events along the interplate contact, the so-called "seismogenic zone", and an intense seismic activity further to the East, in the Andean Cordillera.

[3] For a given area, many factors control the seismic risk. Earthquake Hazard is, of course, the key factor. It can be expressed in terms of magnitude of expected earthquakes, site effects, hypocentral distances, rupture mechanisms, recurrence, etc. Seismic risk is also controlled by the site vulnerability. The vulnerability of northern Ecuador is high: Esmeraldas, a city of $\sim 60,000$ inhabitants, is located in the area. It houses the Ecuadorian oil refinery and shipping terminal, constructed during the early eighties. Moreover, the continental margin exhibits very steep slopes, where submarine landslides may easily be triggered by earthquakes and may be followed by devastating tsunamis.

[4] The historical seismicity of this part of the Andean margin (Figure 2) defines two different segments [Lay et al., 1982; Nishenko, 1991] on either side of the equator:

[5] The southern sector, from the equator down to mid-Peru $\left(10^{\circ} \mathrm{S}\right)$, did not experience historical large $(\mathrm{M}>7.8)$ earthquakes.

[6] The northern sector, however, experienced four historical great $M>8$ subduction earthquakes (Figure 3a). The 1906 earthquake had an estimated 500 to $600 \mathrm{~km}$-long rupture zone that was partially reactivated during three subsequent thrust events: in May, $1942\left(\mathrm{M}_{\mathrm{w}}=7.9\right)$, in January, $1958\left(\mathrm{M}_{\mathrm{w}}=\right.$ 7.8) and in February, $1979\left(\mathrm{M}_{\mathrm{w}}=8.0\right)$ [Herd et al., 1981; Beck and Ruff, 1984; Swenson and Beck, 1996]. Hypocenters were located offshore, near the coastline [Mendoza and Dewey, 1984]. The southern part of the northern sector, around the equator, is considered as a seismic gap [Sykes, 1971; Kelleher, 1972] and is credited of a conditional probability of $60 \%$ to $100 \%$ for the occurrence of either a large or a great earthquake for the period 1989 to present [Nishenko, 1991]. Destructive tsunamis were associated with the 1906 and 1979 earthquakes.

[7] Coastal Ecuador has been characterized as allochthonous terranes of oceanic origin [Goosens and Rose, 1973; Lebrat et al., 1987; Roperch et al., 1987], accreted on the western side of the Andes, during several accretion episodes between Late Jurassic and Eocene (Figure 4). The last episode of Early Tertiary accretion involved oceanic plateaus and island arc terranes forming the coastal block and the Western Cordillera [Jaillard et al., 1997; Hughes and Pilatasig, 2002]. The allochthonous nature of coastal Ecuador is also supported by anomalies in the gravity field [Feininger and Seguin, 1983].

\section{Previous Work in the Area}

[8] In the study area, seismicity from global catalogs such as Preliminary Earthquake Determination (PDE) or International Seismological Catalog (ISC) is poorly constrained, mainly in hypocentral depth and yield a large number of fixed $33 \mathrm{~km}$-depth events. Using Engdhal's Catalog [Engdahl et al., 1998] does not allow to describe accurately the geometry of the slab and the upper and lower limits of the seismogenic zone are still unknown (Figures $3 b$ and $3 c$ ). According to many authors, the slab is subducting eastward with an angle of $25^{\circ}$ to $40^{\circ}$ [Lonsdale, 1978; Pennington, 1981; Prévôt et al., 1996; Taboada et al., 2000]. Others [Gutcher et al., 1999, 2000a, 2000b], propose a $100 \mathrm{~km}$ deep flat slab beneath the Ecuadorian Andes. More recently, Guillier et al. [2001] analyzed the spatial distribution of seismicity in the area from a temporary seismological network located rather far from the shoreline. They found that the slab is continuously plunging down to a depth of $\sim 200 \mathrm{~km}$ with an angle of $25^{\circ}-35^{\circ}$. Near the coast, the seismicity is poorly documented due to the lack of permanent seismological stations.

[9] Centroïd Moment Tensor Solutions (CMTS) from Harvard (Figure 5) clearly show remarkably coherent thrust-type events, with depth ranging 


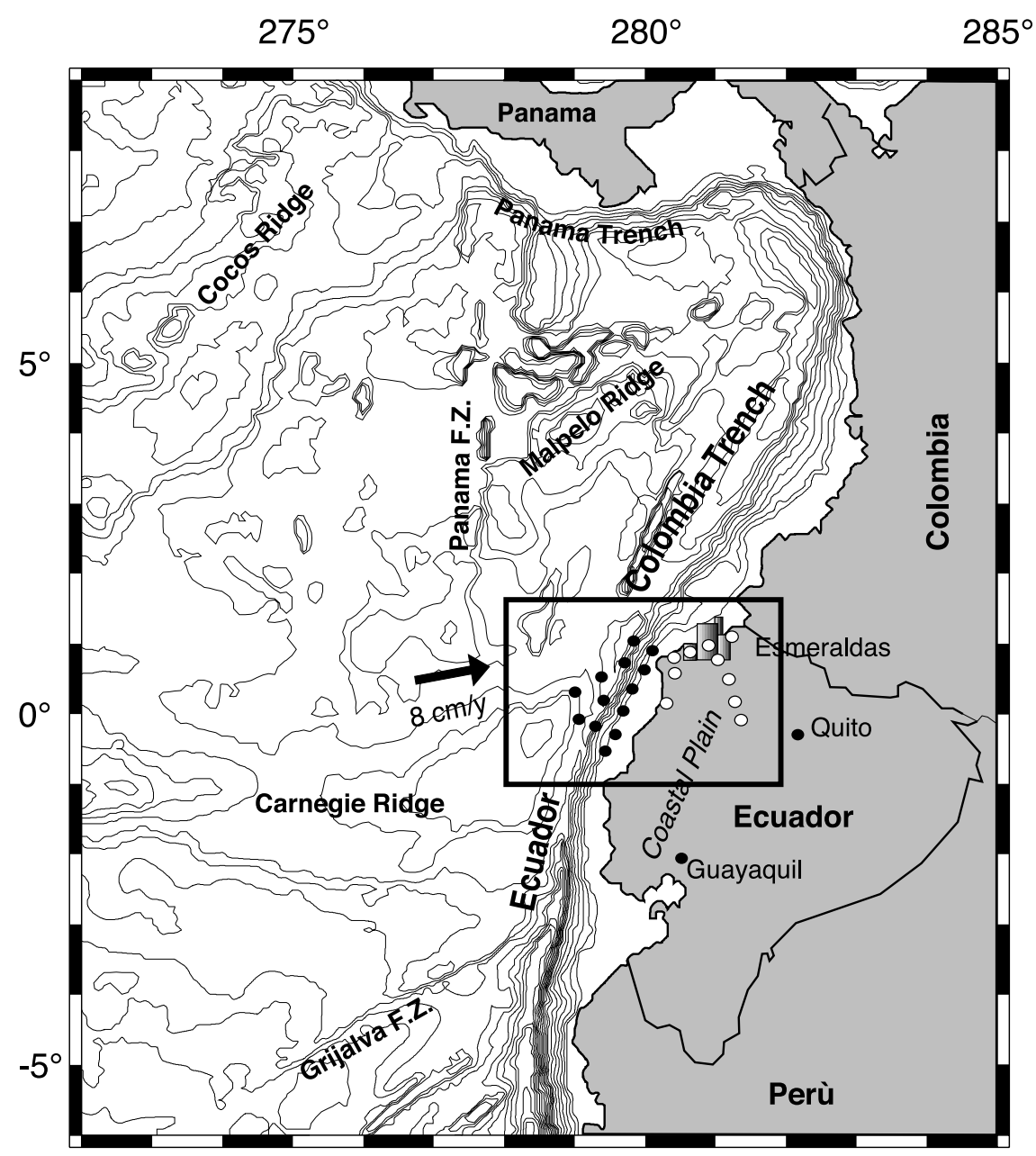

Figure 1. Location of the study area. Black dots represent Ocean Bottom Seismometers (OBS); open circles represent land stations.

between 15 and $40 \mathrm{~km}$ and magnitudes $\mathrm{M}_{\mathrm{w}}>5$. They are almost all restricted to the East of the trench axis and West of the coastline, underneath the margin. This indicates that the bulk of the energy released by the subduction process is along the interplate boundary. The regional stress pattern deduced from CMTS [Legrand et al., 2002] indicates that the $\sigma 1$-axis is oriented $N 117^{\circ} \mathrm{E}$, close to the $\mathrm{N} 102^{\circ} \mathrm{E}$ direction of plate motion deduced from GPS measurements [Kellog and Vega, 1995], while $\sigma 3$-axis is nearly vertical.

[10] The outstanding lack of shallow global seismicity $\left(\mathrm{M}_{\mathrm{w}}>5\right)$ between the coastline and the western slope of the Andes, as mentioned by Guillier et al. [2001], suggests that the basement of the coastal block is a rigid undeforming body, acting as a buttress and transmitting the presentday compressive stress to the Andes.

\section{Field Experiment and Data Processing}

[11] We conducted a passive seismic experiment, in the spring of 1998, in the Esmeraldas area, deploying thirteen Ocean-Bottom Seismometers (OBS) offshore northern Ecuador, using the French R/V Antéa (Figure 6). They were deployed on predetermined sites, using existing precise bathymetric maps (SIMRAD ${ }^{\mathrm{TM}}$ EM12 swath mapping of the French $\mathrm{R} / \mathrm{V}$ l'Atalante) or directly after local surveys using the narrowbeam echo sounder on board the R/V Antéa. A 


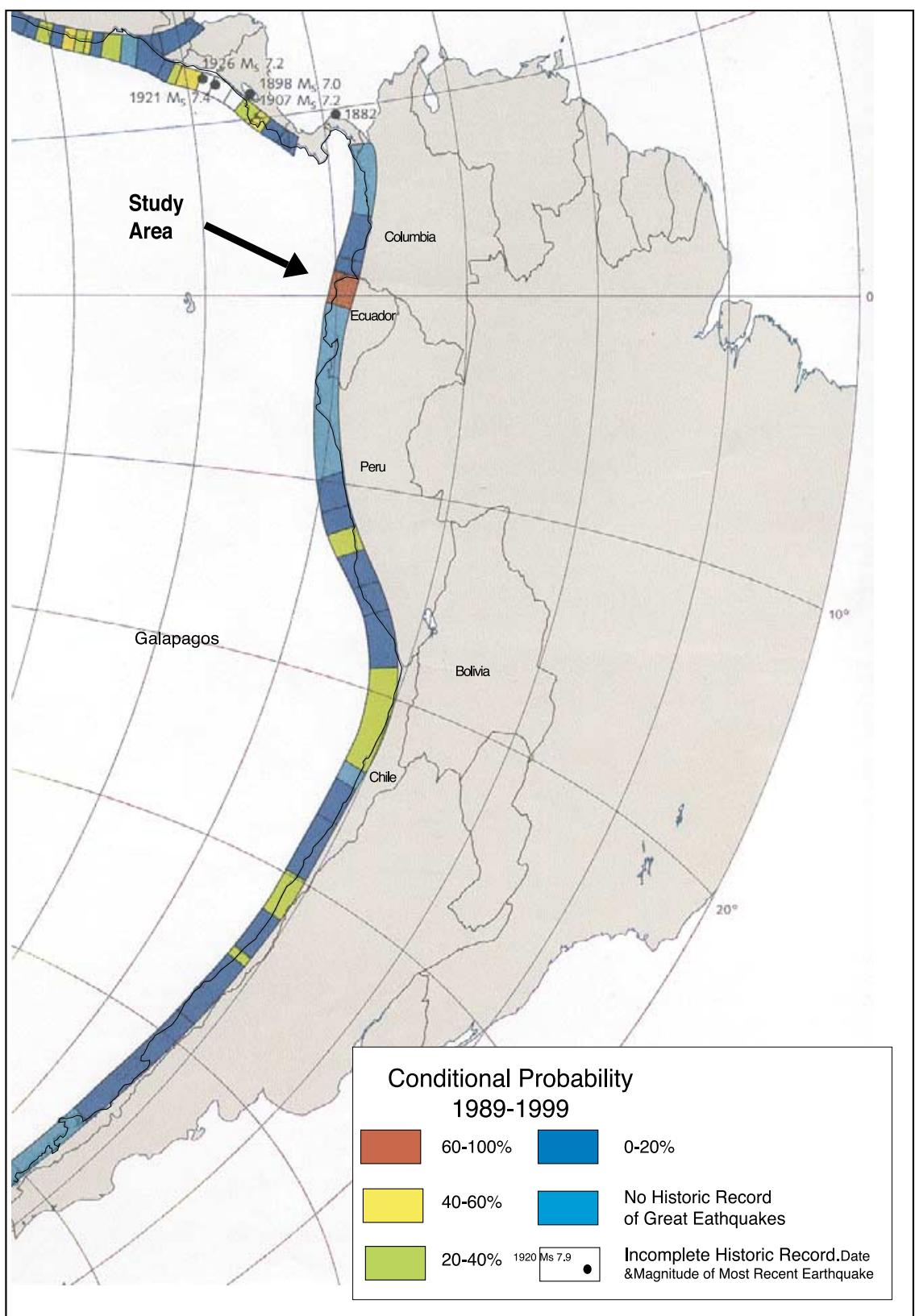

Figure 2. The time-dependent probability for the recurrence of either a large $\left(7.0<\mathrm{M}_{\mathrm{s}}<7.7\right)$ or a great $\left(\mathrm{M}_{\mathrm{s}}\right.$, $\left.M_{w} \leq 7.7\right)$ shallow plate boundary earthquake, within a specified segment during the time interval 1989 to 1999 , conditional upon the event not having recurred prior to 1989. The study area represents the highest probability of the Andean subduction system [after Nishenko, 1991].

sub-array of 10 short period seismometers was also deployed on-land during the same period of time.

[12] The OBSs were designed jointly by IRD (Institut de Recherche pour le Développement, formerly ORSTOM) and UT-IG (University of Texas - Institute of Geophysics) during the early nineties. Their design and use was extensively described by Nakamura et al. [1987], Nakamura and Garmany [1991], Hello et al. [1992]. During the experiment, the 13 OBSs were set in the continuous mode, with a data sampling-rate of 50 samples per second, allowing 3 weeks of recording on three channels ( 1 vertical +2 horizontals gimbaled $4 \mathrm{~Hz}$ Mark-Products ${ }^{\mathrm{TM}}$ geo- 

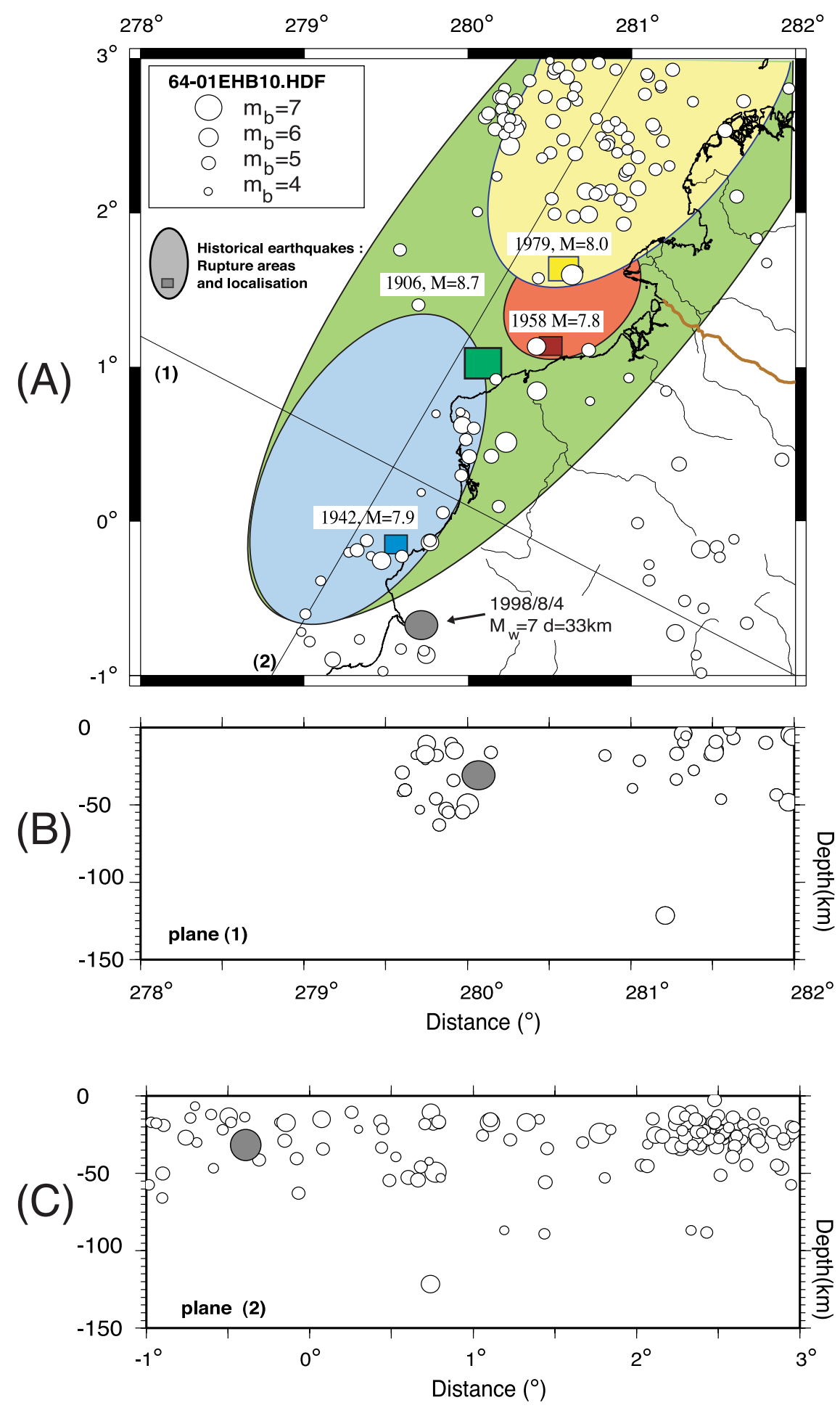

Figure 3. (a) Historical seismicity superimposed with instrumental seismicity as relocated by Engdahl et al. [1998], for the period 1964 to 2001. The gray dot is the 1998/8/4 $\left(\mathrm{M}_{\mathrm{w}}=7\right)$ earthquake from the Preliminary Earthquake Determination (PDE) bulletin. (b): projection on vertical plane 1. (c): projection on vertical plane 2. 


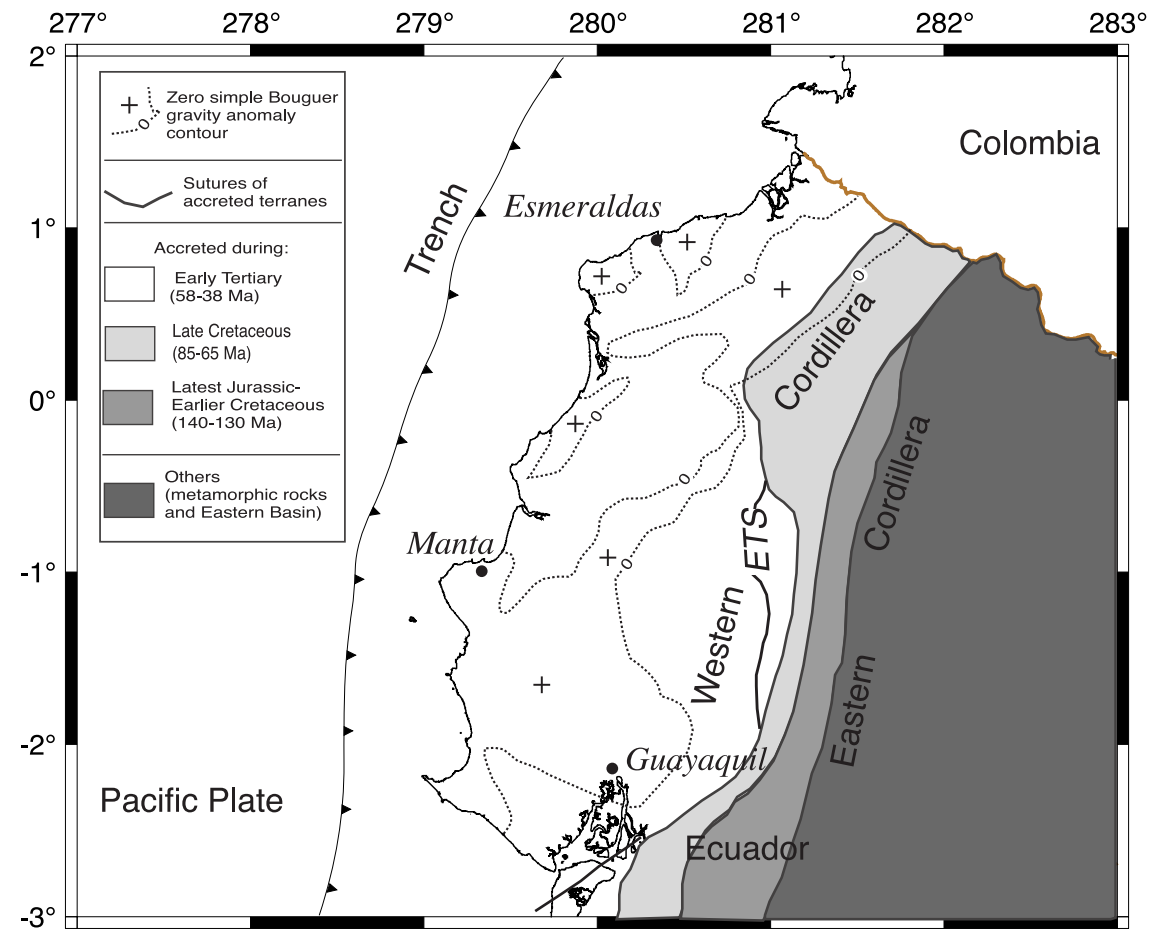

Figure 4. Map of Ecuador with main morphological zones, redrawn from Jaillard et al. [1997]. ETS (Early Tertiary Suture) denotes the last accretion episode in the Early Tertiary. The dotted line is the zero simple Bouguer gravity anomaly contour, redrawn from Feininger and Seguin [1983]. It illustrates the NNE-SSW structural trending of the coastal block in the Esmeraldas-Manta area.

phones). Data A/D conversion 16-bits format (14 data-bits +2 gain-bits) leads to a dynamic range of $\sim 126 \mathrm{~dB}$. A temperature-controlled quartz clock of the acquisition system, calibrated before deployment and after recovery, allows time accuracy of less than $0.05 \mathrm{sec}$.

[13] At the end of the experiment, air-gun surface shots, using a single 5 liters Bolt ${ }^{\mathrm{TM}}$ air-gun, were performed over the stations. Inversion of direct water-wave travel times and $\mathrm{H} 1 / \mathrm{H} 2$ amplitude ratios were used to compute the accurate OBS's seafloor location and orientation, together with extra clock calibration. The location and orientation accuracy is estimated to be less than $50 \mathrm{~m}$ and $3^{\circ}$, respectively. Owing to technical reasons, only 9 OBS were correctly relocated and oriented on the bottom (Figure 6). Bottom location of the four others was estimated using deployment and recovery ship's locations, with an estimated accuracy of $\sim 200 \mathrm{~m}$.

[14] Despite a very unusual high level of noise during the experiment [Pontoise and Hello,
2002], more than 700 earthquakes were detected by the OBS network. The majority of them were only detected by 1 or 2 stations, due to their relatively small magnitude and thus are not included in our database. Among the 700 events, a subset of 111 local earthquakes have $\mathrm{P}$ and $\mathrm{S}$ readings allowing precise locations of hypocenters. The use of automatic detection procedures was not possible due to high noise level. Therefore $\mathrm{P}$ and $\mathrm{S}$ arrival times were picked out manually. S time-picks were made on horizontal components exclusively. Weights are given to time-picks, ranging between 0 (clear phase-pick, full weight) and 4 (no weight). Arrival times accuracy is estimated to be 0.05 and $0.3 \mathrm{~s}$, for $\mathrm{P}$ and $\mathrm{S}$ respectively.

[15] Almost continuous heavy rainfall due to the great 1997-1998 El Niño event caused high levels of noise on the land-stations. In addition, floods and landslides make it difficult to properly maintain the network. Still, the land stations usefully recorded about 50 earthquakes. 


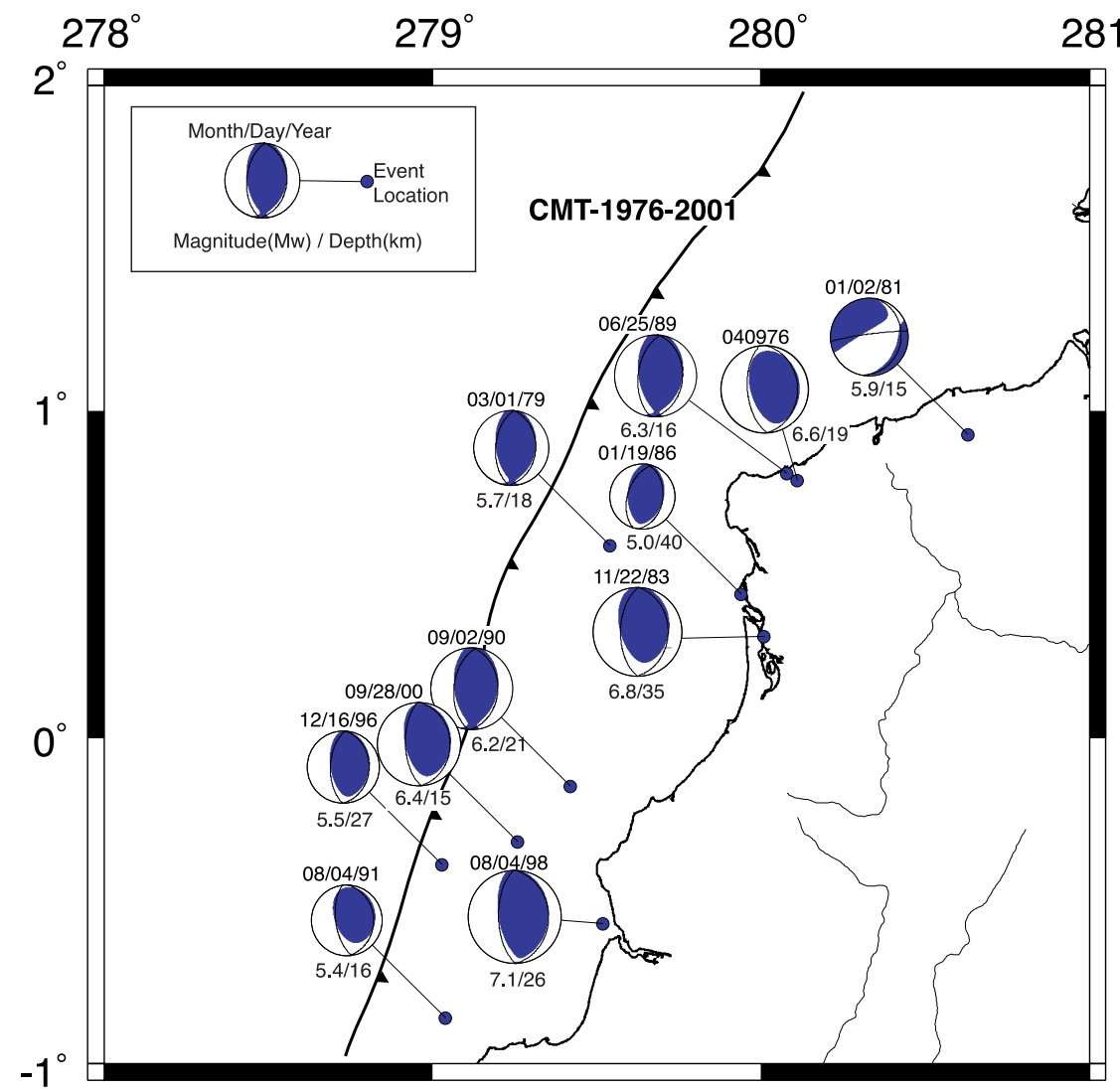

Figure 5. Centroïd Moment Tensor Solutions (Harvard) for the period 1976-2001. Note that all earthquakes occur East of the trench axis and West of the shoreline. Note also that their depths range between 15 and $40 \mathrm{~km}$. All mechanisms are clearly thrust-type mechanisms, with the exception of the easternmost one, which has a normal fault solution.

[16] None of these local earthquakes is indexed in the seismicity global catalogs (PDE, ISC), mainly because of their low magnitude.

\section{Location Procedure and Velocity Structure Estimation}

\subsection{Data Corrections and Location Parameters}

\subsubsection{Unconsolidated Sediments Effects}

[17] The stations located on the oceanic plate exhibit clear $\mathrm{P}$ to $\mathrm{S}$ conversions that often appear on the horizontal components a few seconds after the $\mathrm{P}$ arrival (Figure 7). We assumed that these conversions take place at the sediment-upper crust interface. It is well known that $\mathrm{S}$ velocities in unconsolidated sediments can be as low as 0.4$0.5 \mathrm{~km} / \mathrm{s}$, whereas the $\mathrm{P}$ velocities range between
1.5 and $2 \mathrm{~km} / \mathrm{s}$ [Schreiner et al., 1991; Ayres and Theilen, 1999; Hino et al., 2000]. For the oceanicplate group of stations (i.e., OBS 5, 6 and 7 in Figure 6), a correction is applied to the $\mathrm{S}$ readings in order to account of the sediment-delayed $S$ phases. The theoretical travel time of $S$ phases in the unconsolidated sediments is estimated from sediment thickness, $\mathrm{P}$ velocity of $2 \mathrm{~km} / \mathrm{s}$ and $\mathrm{VP} / \mathrm{VS}=1.8$, whereas the observed travel time of $\mathrm{S}$ phases is estimated with an $\mathrm{S}$ velocity of $0.4 \mathrm{~km} / \mathrm{s}$. Depending on the local sedimentary thickness, the correction ranges between $0.8 \mathrm{~s}$ and $1.2 \mathrm{~s}$. In the study area, the Oceanic plate exhibits a thick unconsolidated pelagic sedimentary layer of around $1 \mathrm{~s}$ Two Way Time (TWT), whereas the continental slope is covered only by 0.2 to $0.4 \mathrm{~s}$ TWT of sediments. Although there are scarce local turbidity-flow and debris-flow deposits in the trench axis, there is no thick extensive 


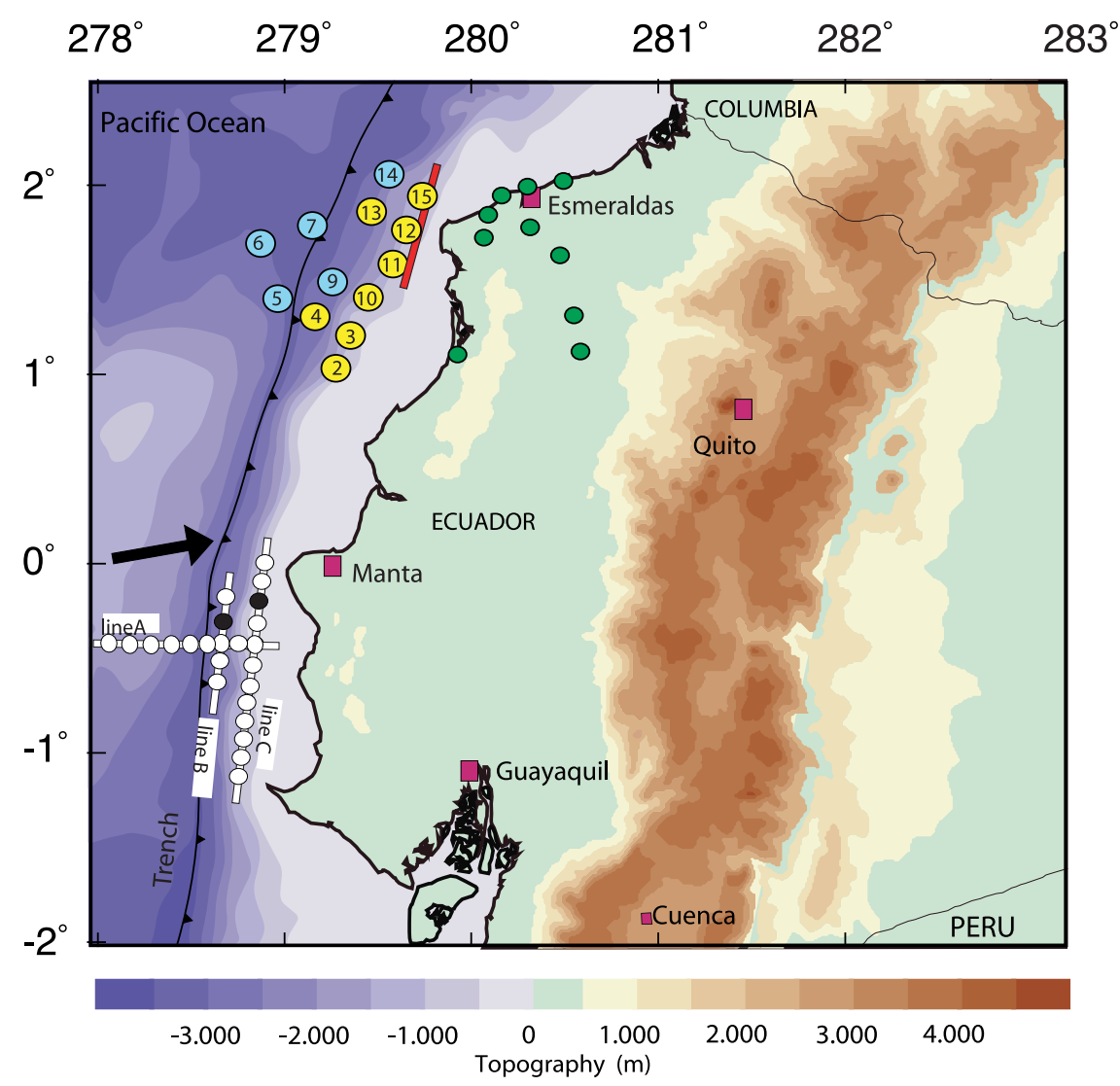

\begin{tabular}{|c|c|}
\hline (3) Relocated OBS & \\
(7) Not relocated OBS & \\
Land station & Multi-Channel \\
Passive Seismological & Multi-Channel/Wide-Angle \\
Experiment & Seismic Experiment \\
(May, 1998) & (September, 2000) \\
\hline
\end{tabular}

Figure 6. Location of passive seismological networks (1998) and Multi-Channel/Wide-Angle seismic experiments (2000). One-Dimensional velocity models are estimated from Wide-Angle data (black dots) recorded in the Manta area, and used to define velocity models for hypocenter determinations in the Esmeraldas area.

turbidites on the continental margin because of limited terrigenous supply [Lonsdale, 1978]. Thus we consider that the $\mathrm{S}$ phases are not significantly delayed for the continental slope group of stations.

\subsubsection{Location Parameters}

[18] A minimum of 5 phase-picks is required before events are located, the average number of $\mathrm{P}$ and/or $\mathrm{S}$ time picks is 10 and the largest is 32 . No minimum gap (largest azimuthal separation between stations as seen from the epicenter) is required, but gap values strongly influence the quality of the determination. Quality ranges between $\mathrm{A}$ and $\mathrm{C}$, based on horizontal and vertical errors SEH and SEZ (Single Estimate Horizontal $68 \%$ confidence limit in the least-well constrained direction and Single Estimate Vertical 68\% confidence limit for depth) and gap. Following Lahr [1999], the classification is given by Table 1 .

[19] $\mathrm{P}$ and $\mathrm{S}$ arrival times are removed from the location procedure if their residuals are $>5 \mathrm{~s}$. The top of the velocity model corresponds to the depth 


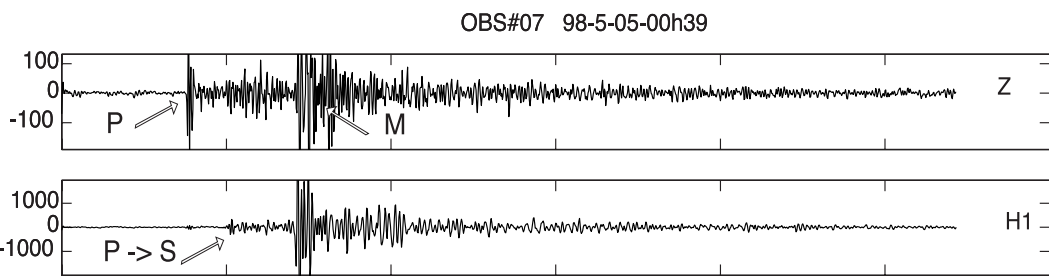

(A)

\section{(B)}

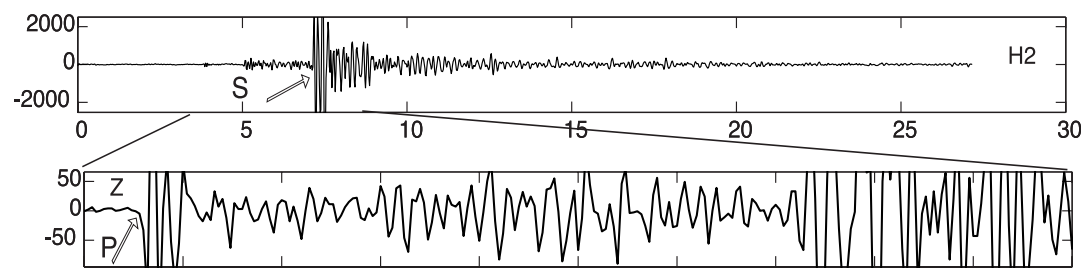

Event :

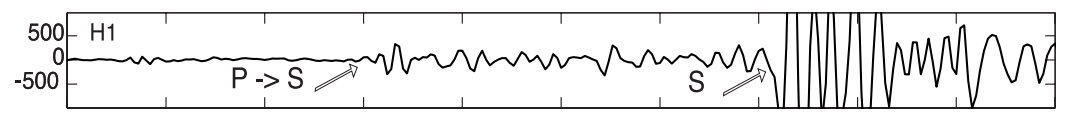

Origin : $98-05-05$ 00:39 43.11
lat=0n39.49 lon $=80 \mathrm{w} 46.66$
depth $=16.25 \mathrm{~km} \quad \mathrm{rms}=0.09 \mathrm{~s}$
distance $=8.8 \mathrm{~km}$
seh1 $=0.5$ seh2=0.8 sez $=1.4$
quality $=$ A

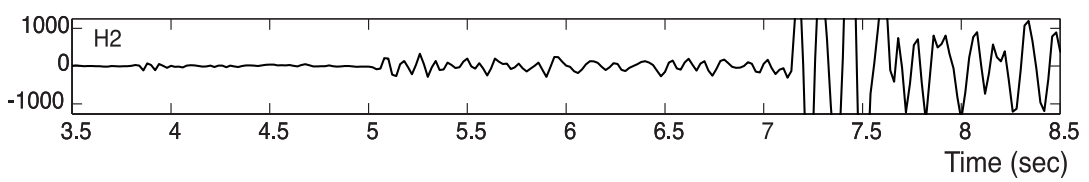

Figure 7. Example of converted $\mathrm{P}$ to $\mathrm{S}$ waves for "oceanic group" OBS \#7. Conversion between $\mathrm{P}$ to $\mathrm{S}$ is from the interface between the upper igneous crust and unconsolidated oceanic sediments. $\mathrm{P} \rightarrow>\mathrm{S}$ denotes the converted waves, $\mathrm{M}$ denotes the multiple in the water column. Figures $7 \mathrm{a}, 7 \mathrm{~b}$, and $7 \mathrm{c}$ are the three components: $\mathrm{Z}, \mathrm{H} 1$ and $\mathrm{H} 2$, respectively. Figures 7d, 7e, and 7f are close views of Figures 7a, 7b, and 7c.

of the deepest OBS $(3250 \mathrm{~m})$ and this value is added to the calculated depth. Station corrections are applied, using a constant $3.5 \mathrm{~km} / \mathrm{s}$ velocity and the ray incidence at the station.

[20] The $\mathrm{V}_{\mathrm{p}} / \mathrm{V}_{\mathrm{s}}$ ratio was obtained using $\left(\mathrm{S}_{\mathrm{i}}-\mathrm{S}_{\mathrm{j}}\right)$ versus $\left(\mathrm{P}_{\mathrm{i}}-\mathrm{P}_{\mathrm{j}}\right)$ method [Chatelain, 1978]. For a given pair of stations $(i, j)$ at hypocentral distances $\mathrm{x}_{\mathrm{i}}$ and $\mathrm{x}_{\mathrm{j}}$, the difference of $\mathrm{P}_{\mathrm{i}, \mathrm{j}}$ and $\mathrm{S}_{\mathrm{i}, \mathrm{j}}$ arrival times can be expressed as:

$$
\mathrm{P}_{\mathrm{i}}-\mathrm{P}_{\mathrm{j}}=\left(\mathrm{x}_{\mathrm{i}}-\mathrm{x}_{\mathrm{j}}\right) / \mathrm{V}_{\mathrm{p}} \text { and } \mathrm{S}_{\mathrm{i}}-\mathrm{S}_{\mathrm{j}}=\left(\mathrm{x}_{\mathrm{i}}-\mathrm{x}_{\mathrm{j}}\right) / \mathrm{V}_{\mathrm{s}}
$$

[21] Therefore the plot of $\left(S_{i}-S_{j}\right)$ versus $\left(P_{i}-P_{j}\right)$ for all available pairs of stations defines a straight line, the slope of which is $\mathrm{V}_{\mathrm{p}} / \mathrm{V}_{\mathrm{s}}$. Weights are defined for pairs of $\mathrm{P}_{\mathrm{i}, \mathrm{j}}$ and $\mathrm{S}_{\mathrm{i}, \mathrm{j}}$ as the highest weight of the four $\mathrm{P}$ and $\mathrm{S}$ weights. Plotting only weights of 0,1 or 2 , the $\mathrm{V}_{\mathrm{p}} / \mathrm{V}_{\mathrm{s}}$ ratio measured in the study area is $1.81 \pm 0.01$ (Figure 8).

\subsection{Best 1-D Model}

[22] Our first attempts to locate the hypocenters, using the HYPO71 program [Lee and Lahr, 1975] with a wide variety of velocity models, led to poorly constrained hypocenters having extremely large scatters. For the best 1-D velocity model, $31 \%$ of the events were of D quality, indicating that (1) time picks have to be corrected, (2) a 2-D velocity model (or 3-D) is required and/or (3) a velocity inversion is present in the area of interest.

[23] The next step was to determine an average 1-D-velocity model using the VELEST algorithm [Kissling et al., 1995]. First, we relocated the earthquakes with VELEST without varying the velocity model. Then, this relocation was used as initial event location for a joint inversion process to determine the best average 1-D velocity model and the associated earthquake locations. Though we performed several VELEST runs using different

Table 1. Quality of Determination and Associated Errors

\begin{tabular}{cc}
\hline Quality & Larger of SEH and SEZ, km \\
\hline A & $\leq 1.34$ \\
B & $\leq 2.67$ \\
C & $\leq 5.35$ \\
D & $>5.35$ \\
\hline
\end{tabular}




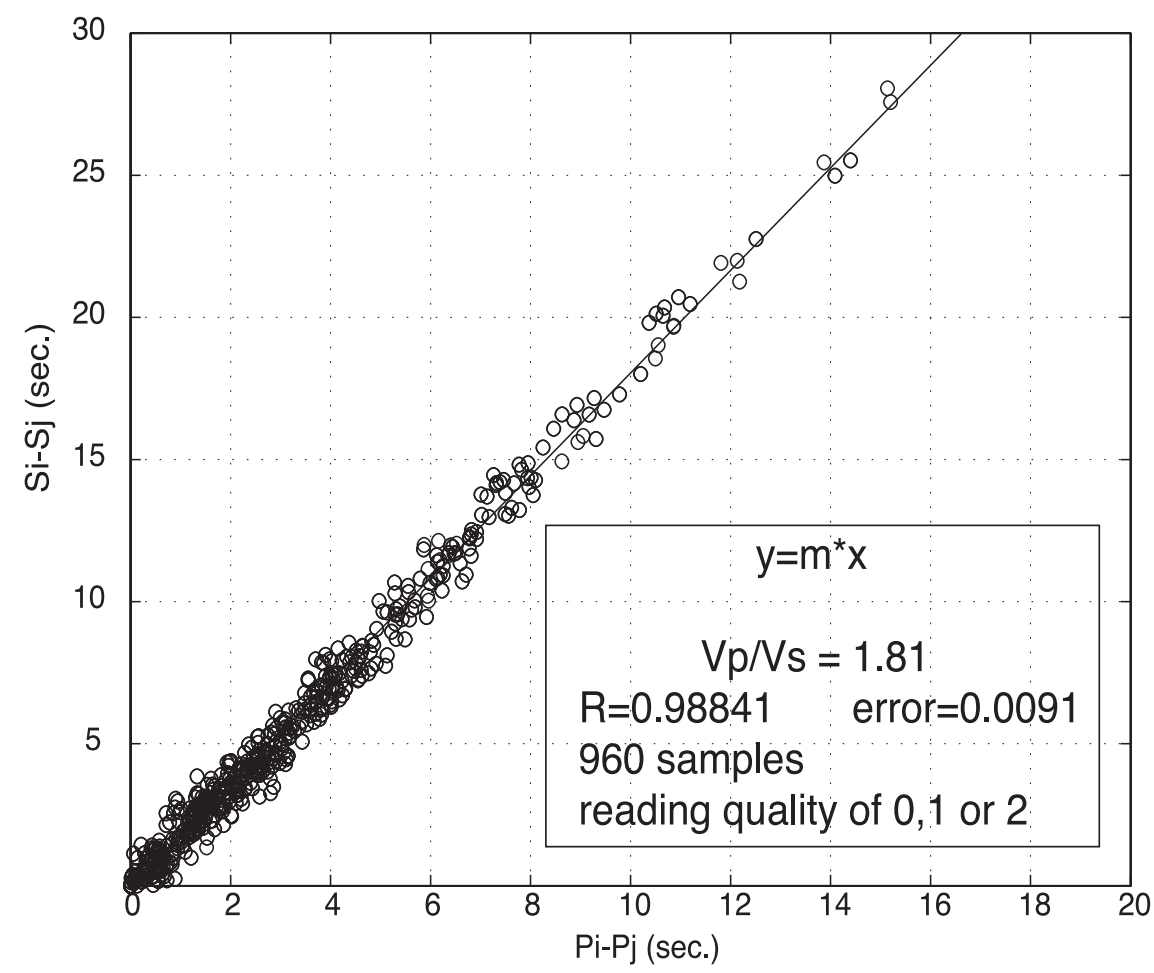

Figure 8. Plot of $\left(S_{i}-S_{j}\right)$ versus $\left(P_{i}-P_{j}\right)$ for all available $P$ and $S$ readings for every pairs of stations $i$ and $j$ (see text for explanations). The linear linear fitting yields the local $\mathrm{V}_{\mathrm{p}} / \mathrm{V}_{\mathrm{s}}$ ratio of 1.81 .

starting 1-D-velocity models, there was no convergence to a stable minimum, probably because of the relatively small number of located events (only 111 ), and their loose distribution in the network.

[24] To change strategy, we selected the HYPOELLIPSE [Lahr, 1999] computer program because it allows multiple 1-D velocity models and velocity inversions for the propagation model. Figure 9 shows the result of applying time corrections for oceanic domain stations $\mathrm{S}$ waves picks, using the best 1-D velocity model as previously defined. After $\mathrm{S}$ time correction, hypocenters are less scattered (black dots) than before correction (open circles), mainly in the oceanic domain, i.e., between $279^{\circ}$ and $297.5^{\circ}$. The percentage of correctly determined

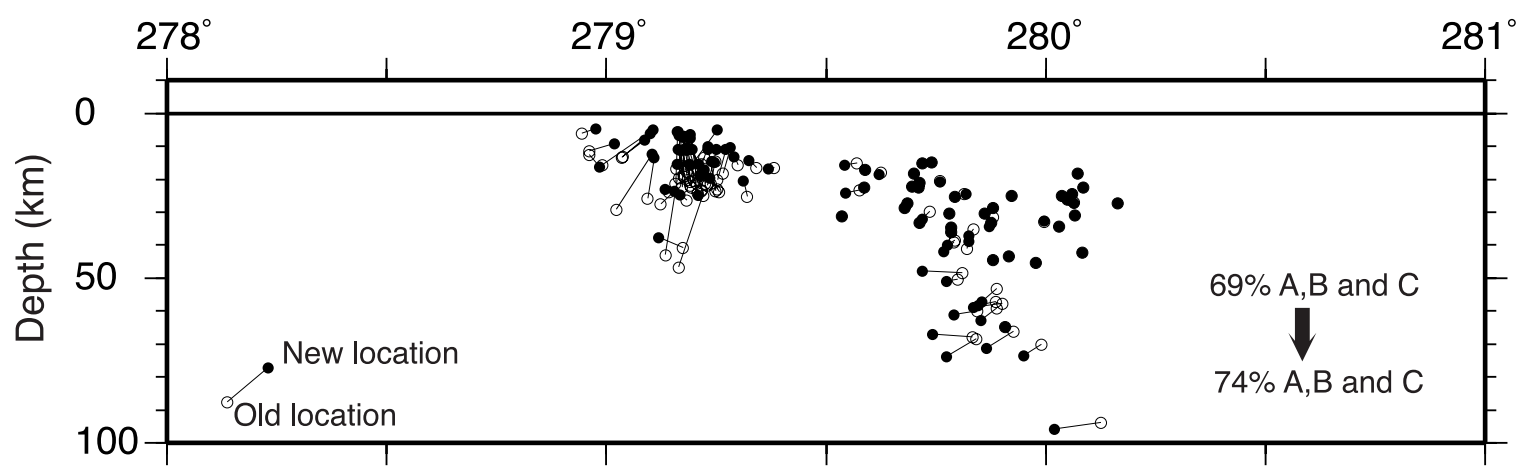

Figure 9. Vertical cross section with hypocenters projected onto plane 1 (see Figure 3 and Figure 16 for location of the plane 1) showing the effect of the $\mathrm{S}$ time-picks corrections due to the presence of thick unconsolidated pelagic sediments on the oceanic plate. Open circles are locations using the best 1-D model as described in the text. Black dots are location after applying the $\mathrm{S}$ time-pick correction. Note that the hypocenters after $\mathrm{S}$ time-pick correction are less scattered than before correction, mainly in the oceanic domain. The percentage of correctly determined hypocenters (i.e., A, B and C) increases from $69 \%$ to $74 \%$ during this operation. 
hypocenters, i.e., quality A, B and C, increases from $69 \%$ to $74 \%$ during this operation.

\subsection{2-D Model Deduced From Wide-Angle Experiment}

[25] Until recently, the velocity model of the area was poorly known. Previous work [Prévôt et al., 1996] to determine the velocity structure beneath the Ecuadorian Andes, using data from the Ecuadorian Permanent Seismic Network, resulted in a coarse model $(60 \times 60 \mathrm{~km}$-blocks $)$ that is not adequate for our local study. Because of the oceanic origin of the Ecuadorian Coastal Block and the possible presence of sedimentary layers trapped beneath the margin, we suspect the presence of a velocity inversion in the area.

[26] Following the geological characteristics of the different sites, the network can be divided into four different groups of stations: (1) Sites 5, 6 and 7, to the West of the trench, are lying on subducting oceanic crust [Lonsdale and Kiltgord, 1978], formed on the extinct Malpelo Ridge 10 to $15 \mathrm{My}$ ago. (2) Sites 4, 9, 13 and 14 are located some $11 \mathrm{~km}$ East of the trench, near the rim of the continental margin, where the upper-plate structure is expected to be thin. (3) Sites 2, 3, 10, 11, 12 and 15 are located on the upper part of the slope, some $35 \mathrm{~km}$ East of the trench axis and just to the West of the continental slope-break. (4) On land, sites are located at distances ranging between 66 to $140 \mathrm{~km}$ from the trench axis, where the upper-plate structure is expected to be thick.

[27] During the fall of 2000, a Multi-Channel Seismic (MCS) and a Wide-Angle Seismic (WAS) experiment offshore Ecuador was performed in the Manta area, $100 \mathrm{~km}$ South of the Esmeraldas area (see Figure 6 for location). For WAS, shots were performed using a tuned array of $8 \times 16$ liters Bolt $^{\mathrm{TM}}$ air -guns with $100 \mathrm{~m}$ closely spaced shots.

[28] Recent structural surveys, especially near Japan, showed that the crustal structure around subduction zones varies from place to place, even for the same subduction zone [Tsuru et al., 2000]. They also showed that the velocity structure relate to the seismic activity caused by physical proper- ties changes at the plate boundary [Kasahara et al., 2001; Fujie et al., 2002]. Nevertheless, we decided to determine the velocity structure obtained in the Manta area and to apply it in the Esmeraldas area in order to locate the earthquakes recorded during our passive seismological survey. Geophysical arguments, such as the NNE-SSW orientation of the gravity anomalies in the Manta-Esmeraldas region (see Figure 4) and comparison between the different results of hypocenters location will bear out this assumption.

[29] In order to obtain preliminary 1-D velocity models that could be applied to the study area, we selected several sites from the WAS experiment (Figure 6). One OBS, located along the line B, is selected to determine lower-slope velocity structure, and another one, located along the line $\mathrm{C}$, to determine the upper-slope velocity structure. The oceanic crust wide-angle data (line A on Figure 6) are not used in our study because the western part of the line lies on the southern extension of the Carnegie Ridge. Its velocity structure is, therefore, likely to represent thickened oceanic crust [Sallarès et al., 2002] which it is not the case in the Esmeraldas area. Therefore our statement to estimate the oceanic crustal structure of the Esmeraldas area is developed below.

\subsubsection{Oceanic Crust Velocity Model}

[30] First, for the sedimentary cover, we used a velocity of $2 \mathrm{~km} / \mathrm{s}$ with a thickness of $1 \mathrm{~km}$, as mentioned above. Second, for the igneous part of the oceanic crust, we used a typical oceanic crustal structure for a 3 to 15 My-old crust [White et al., 1992]. Following the igneous crust velocity models, Oceanic layer II is commonly identified as the standard extrusive basaltic lavas and dykes, formed at the spreading center, with compressional seismic velocities ranging between 4.5 and $5.5 \mathrm{~km} / \mathrm{sec}$ and with an average thickness of $1.7 \mathrm{~km}$. Oceanic layer III primarily consists of intrusive gabbroic rocks, with typical velocities of 6.2 to $7 \mathrm{~km} / \mathrm{sec}$. The proposed 1-D oceanic crust velocity model is illustrated in Figure 10.

\subsubsection{Upper-Margin Velocity Model}

[31] Figure 11 shows a record-section (using a reduction velocity of $6.6 \mathrm{~km} / \mathrm{sec}$ ) for the OBS 


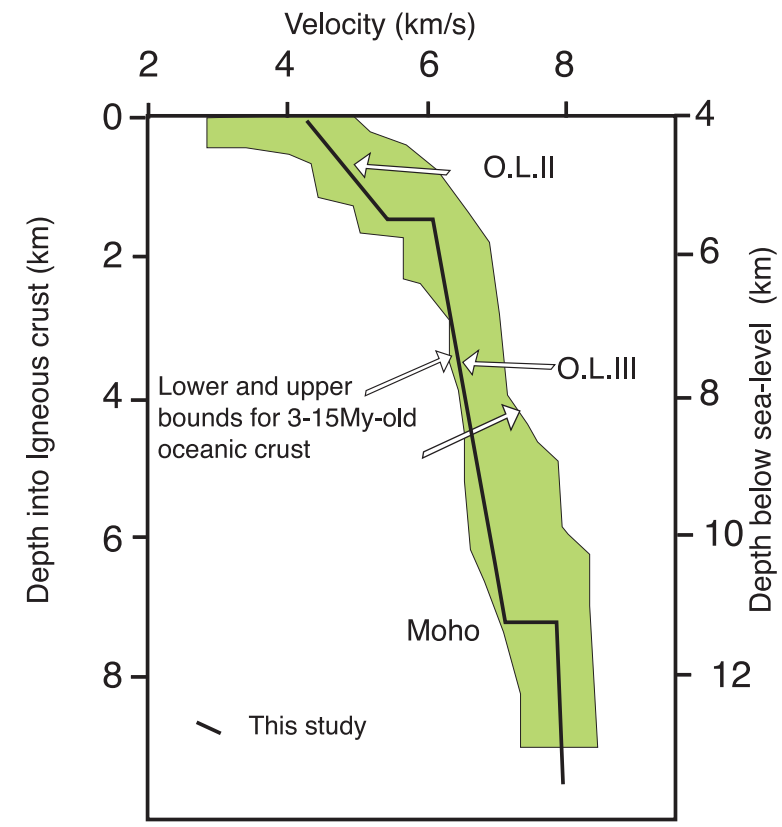

Figure 10. Oceanic crust velocity-depth model used for this study, superimposed with the "stacked velocitydepth curves" for a 3 to 15 My-old Oceanic crust. Redrawn from White et al. [1992].

located along the WAS line C (see Figure 6 for location) on the upper part of the margin. Direct modeling of arrival times was performed using 1-D and 2-D ray-tracing conventional method [Luetgert, 1992].

[32] A remarkable feature of this section is a shadow zone, at about $30-40 \mathrm{~km}$ on either side of the recording station, producing a time-shift of almost 1 -sec. This type of shadow zones is observed on almost all record-sections of the WAS lines B and C [Calahorrano, 2001; Gailler, 2002]. They are unambiguously interpreted as the seismic signature of a Low Velocity Zone (LVZ). We assume that the velocity inversion is due to the contrast between the overlying crust forming the coastal block (with relatively high seismic velocities of $\sim 5.2 \mathrm{~km} / \mathrm{sec}$ ), and the oceanic layers I and II of the downgoing oceanic crust. This interpretation is similar to those of Calahorrano [2001], Gailler [2002], Charvis et al. [2002], and Gailler et al. [2003].

[33] As already mentioned, the oceanic crust in the Manta area is characterized by the presence of the Carnegie Ridge, which is likely to consist of a thickened oceanic layers. Layers II and III are found here to be $4 \mathrm{~km}$-thick and $12 \mathrm{~km}$-thick, respectively. In the Esmeraldas area, the subducting oceanic crust is supposed to be a "normal" 8 15 My-old oceanic crust, as described before. Therefore we will use a composite velocity model as follows: (1) a slightly thickened upper coastal block, as defined in the Manta area, slightly thickened because the upper slope stations in our seismological experiment stand further from the trench axis $(40 \mathrm{~km})$ than in the Manta area $(30 \mathrm{~km})$. This upper part of the model extends from 0 to $6.5 \mathrm{~km}$, (2) a $1 \mathrm{~km}$-thick sedimentary layer and a $1.5 \mathrm{~km}$-thick normal oceanic layer II, (3) a $6 \mathrm{~km}$ thick normal oceanic layer III overlying the mantle.

\subsubsection{Lower-Margin Velocity Model}

[34] The same characteristics (high velocity of the coastal block layers, velocity inversion and oceanic structure below) are found on the record section of the WAS line B. We defined a composite model for the lower-margin group of stations as we did previously for the upper-margin group of stations: (1) the upper coastal block, as defined in the Manta area. This upper part of the model extends from 0 to $4 \mathrm{~km}$, (2) the LVZ composed of a $1 \mathrm{~km}$-thick sedimentary layer, (3) and a $1.5 \mathrm{~km}$-thick and a $6 \mathrm{~km}$-thick normal oceanic layers II and III overlying the mantle.

\subsubsection{Onshore Model}

[35] The 1-D velocity model for the coastal block is derived from the model described for the uppermargin velocity model, but with slightly thicker layers. In this model, the Moho depth reaches $28 \mathrm{~km}$.

\section{Final Hypocenters Determination}

[36] We applied the four 1-D models described above: oceanic model is selected for the oceaniccrust group of stations (OBS 5, 6 and 7), lower slope and upper slope models are selected for lower-slope group of stations (OBS 4, 9, 13 and 14) and upper-slope group of stations (OBS 2, 3, 10, 11, 12 and 15), respectively. The upper-slope model was also used for land-stations, but with slightly thicker layers. 


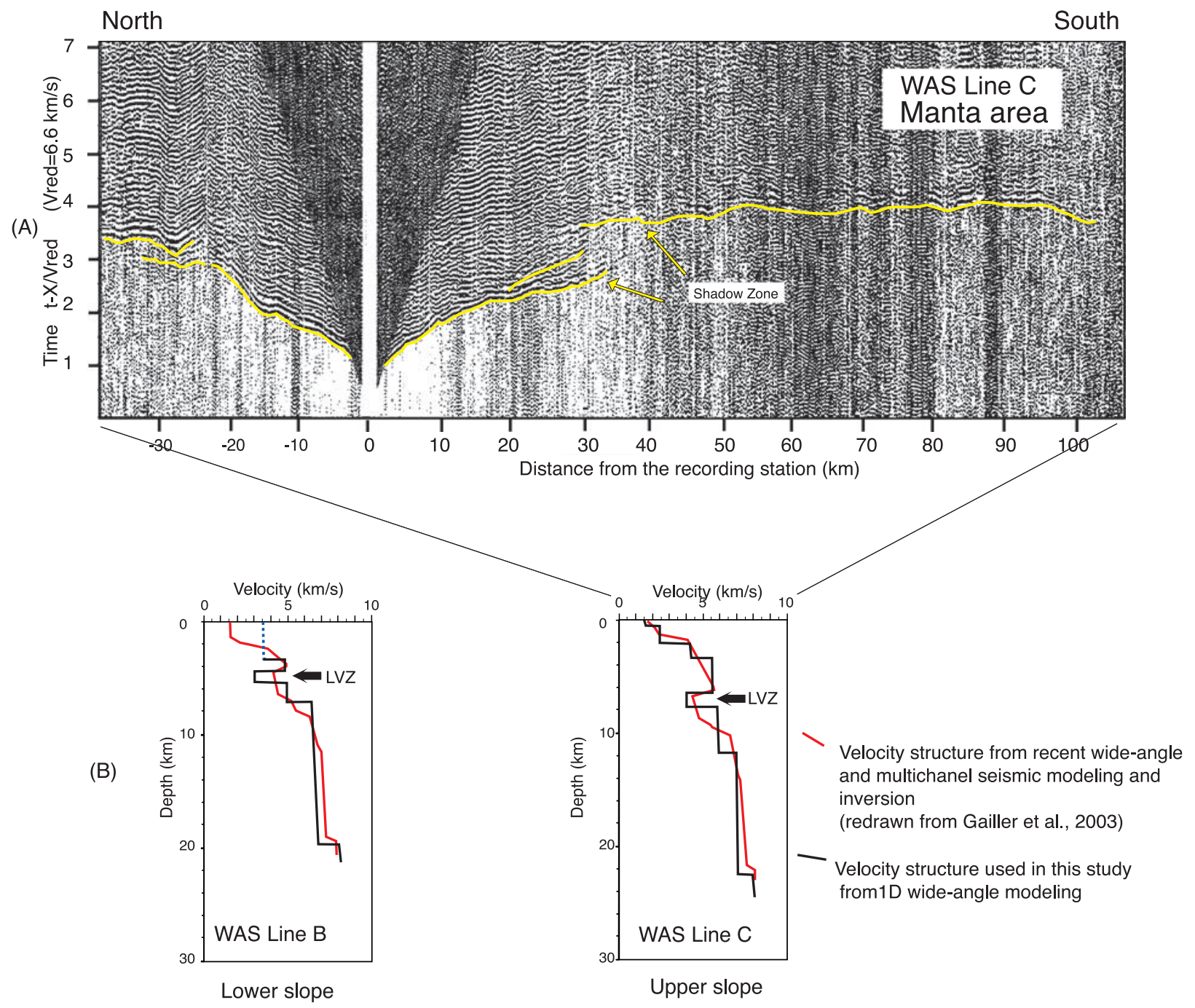

Figure 11. (a) Wide-Angle record-section along the upper part of the margin (Wide-Angle line $\mathrm{C}$, recording station indicated by the northern most black dot) obtained during the WAS experiment (2000), in the Manta area. The vertical scale is reduced time, using a velocity reduction of $6.6 \mathrm{~km} / \mathrm{s}$, the horizontal scale is offset (distance from shots to station) in $\mathrm{km}$. The yellow line highlights the first arrivals along the profile. Note the presence of a shadow zone in the arrival times, between 30 and $40 \mathrm{~km}$ south of the recording station. This shadow zone is present on all record sections of the WAS lines B and C. (b) One-dimensional velocity models deduced from WAS lines B and C. From left to right we present: (1) the lower slope domain (1-D model derived from line B, see Figure 6 for location), and (2) the upper slope domain (1-D model derived from line C, see Figure 6 for location). Note the velocity inversion, indicated by LVZ, that explains the observed shadow zone on the data. This set of two 1-D models, obtained in the Manta area, is used to define the 2-D model used for final hypocenter locations in the Esmeraldas area (see text for explanations).

[37] Figure 12 shows the results of using the 2-D model, as described above, for the different group of stations to locate the earthquakes of the Esmeraldas area. The percentage of hypocenters with quality $\mathrm{A}$ to $\mathrm{C}$ increases from $74 \%$ (open circles) to $85 \%$ (black dots) during this operation. The hypocenters are significantly less scattered than when using single 1-D model. Comparison between the results obtained for single 1-D and 2-D velocity structures a posteriori bears out the use of the velocity structures in the Manta area, $100 \mathrm{~km}$ to the South of the Esmeraldas area.

[38] The final errors (SEH, SEZ, RMS and Gap) associated with hypocenter locations are illustrated in Figure 13 for each class of events. 


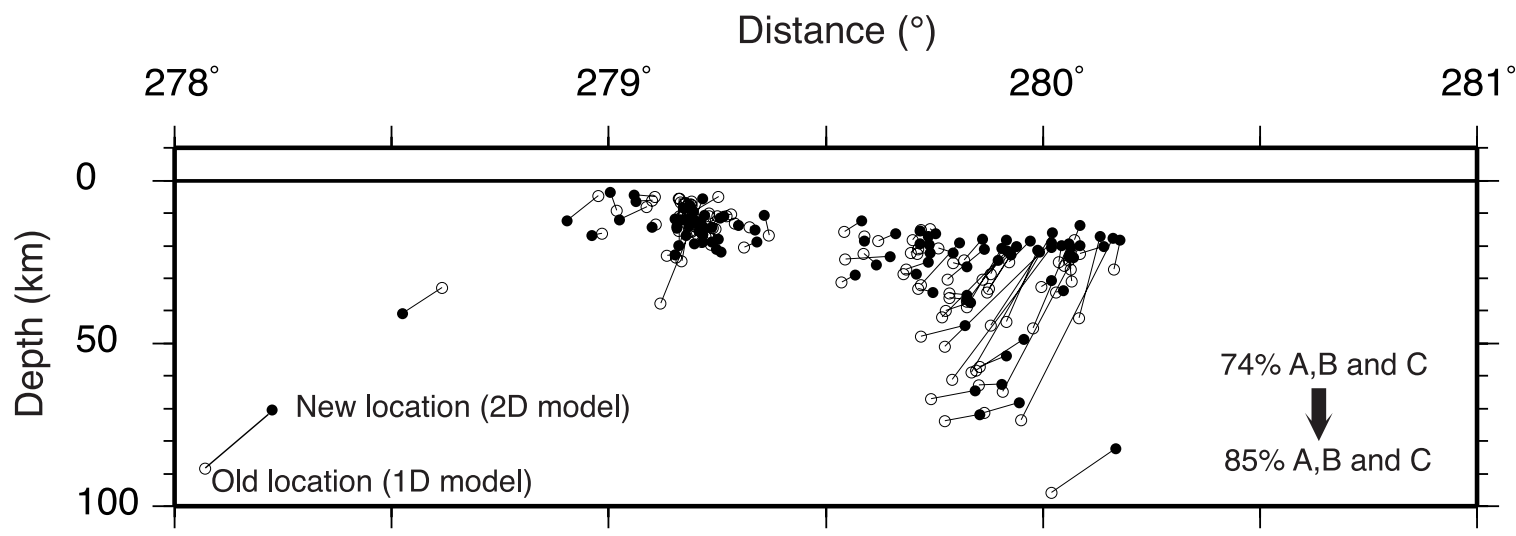

Figure 12. Vertical cross section with hypocenters projected onto plane 1 (see Figure 3 and Figure 16 for location of the plane 1) showing the effect of the 2-D structure on hypocenters location. Open circles are locations using the best 1-D model as described in the text and after S corrections (i.e., solid circles of Figure 10b). Black dots are locations using the 2-D structure as described in the text. Note that the hypocenters calculated for the 2-D structure are less scattered than those calculated for the 1-D structure. The percentage of correctly determined hypocenters (i.e., A, B and C) increases from $74 \%$ to $85 \%$ during this operation.

[39] In the 85 percents of correctly determined hypocenters (quality A, B and C), class A events represent $18 \%$, class $\mathrm{B}, 41 \%$ and class $\mathrm{C}, 26 \%$ of the total numbers or earthquakes. Mean RMS (root mean squares) is $0.22 \mathrm{~s}$.

[40] Figure 14 presents the horizontal projection of error ellipsoids (A) and the vertical errors projected on the vertical plane 1 (B). Most of the large error bars are associated with quality $\mathrm{D}$ hypocenters.

[41] Figure 15a shows the final locations of the 111 hypocenters. Figures $15 \mathrm{~b}$ to $15 \mathrm{e}$ shows hypocenters from our database projected onto vertical planes 1 and 2 together with hypocenters from the Permanent Ecuadorian Network catalog.

\section{Discussion and Conclusion}

[42] In subduction systems, Tichelaar and Ruff [1991] refined the well-known concept of seismogenic zone as the depth-range of a subducting plate where large underthrusting events occur. It represents the seismically coupled zone. The Updip Limit (UdL) and Downdip Limit of the seismogenic zones are important factors in seismic and tsunami hazard assessment.

[43] The UdL, located near the trench, is a key parameter for tsunami generation. For some subduction zones, the UdL is located at $\sim 10 \mathrm{~km}$ depth, and is attributed to underplating of uncon- solidated or semi-consolidated sediments [Byrne et al., 1988] or to a transition in the physical properties of subducting sediments [Vrolijk, 1990].

[44] The Downdip Limit determines the deeper extent of the seismic rupture zone, which is of major importance for hazard estimation at inland localities. Tichelaar and Ruff [1993] analyzed the maximum depth extent of the seismogenic zone along the circum-Pacific subduction zones. For most subduction zones, they proposed that the depth of the Downdip Limit of the seismogenic zone is $40 \pm 5 \mathrm{~km}$. In some specific areas, as in northern Chile, the Downdip Limit edge of the seismogenic zone is found to be $\sim 60 \pm 10 \mathrm{~km}$, on the basis of change from tensional to compressional stress field along the upper part of the subducting slab [Comte and Suarez, 1995].

[45] Some major points have to be highlighted and discussed.

[46] 1. Our data set constituted with microearthquakes recorded during a 3-weeks-only experiment is very representative of the epicentral distribution of the seismic activity reported by others catalogs (ISC, EPN, Engdhal), especially near the shoreline, between $0^{\circ}$ and $1^{\circ} \mathrm{N}$ and close to Esmeraldas city, $1^{\circ} \mathrm{N}-280^{\circ} .5 \mathrm{~W}$ (Figure 16). However, our hypocentral depth is substantially better constrained than that of the catalogs. 
(A)
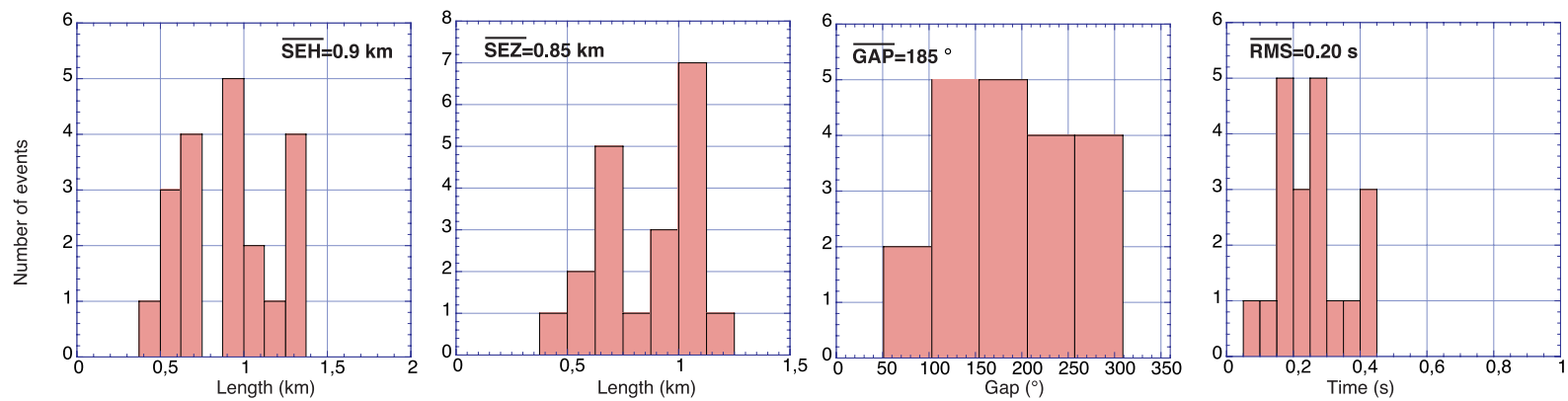

(B)
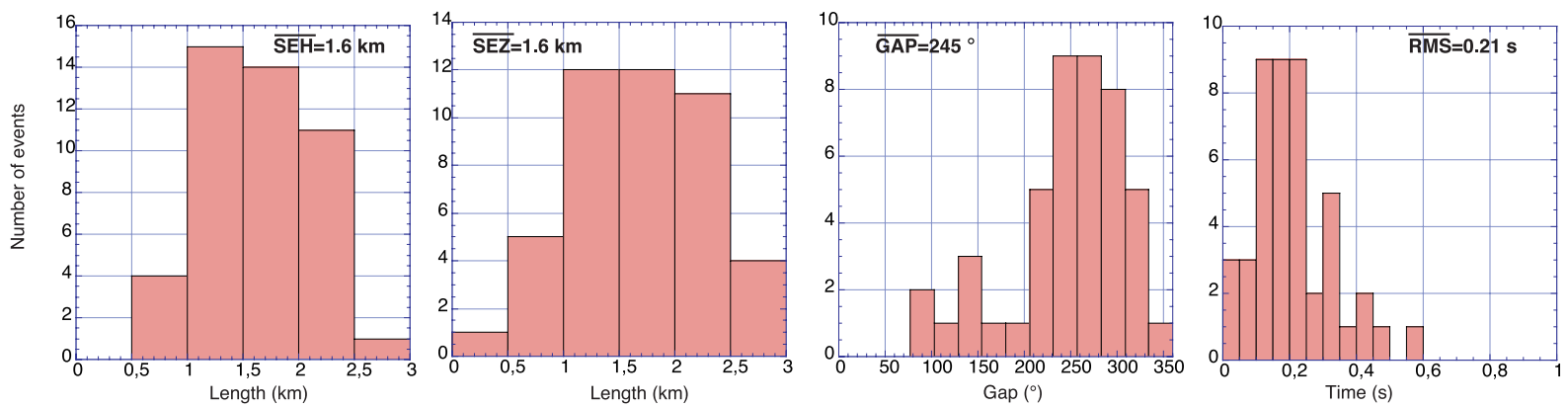

(C)
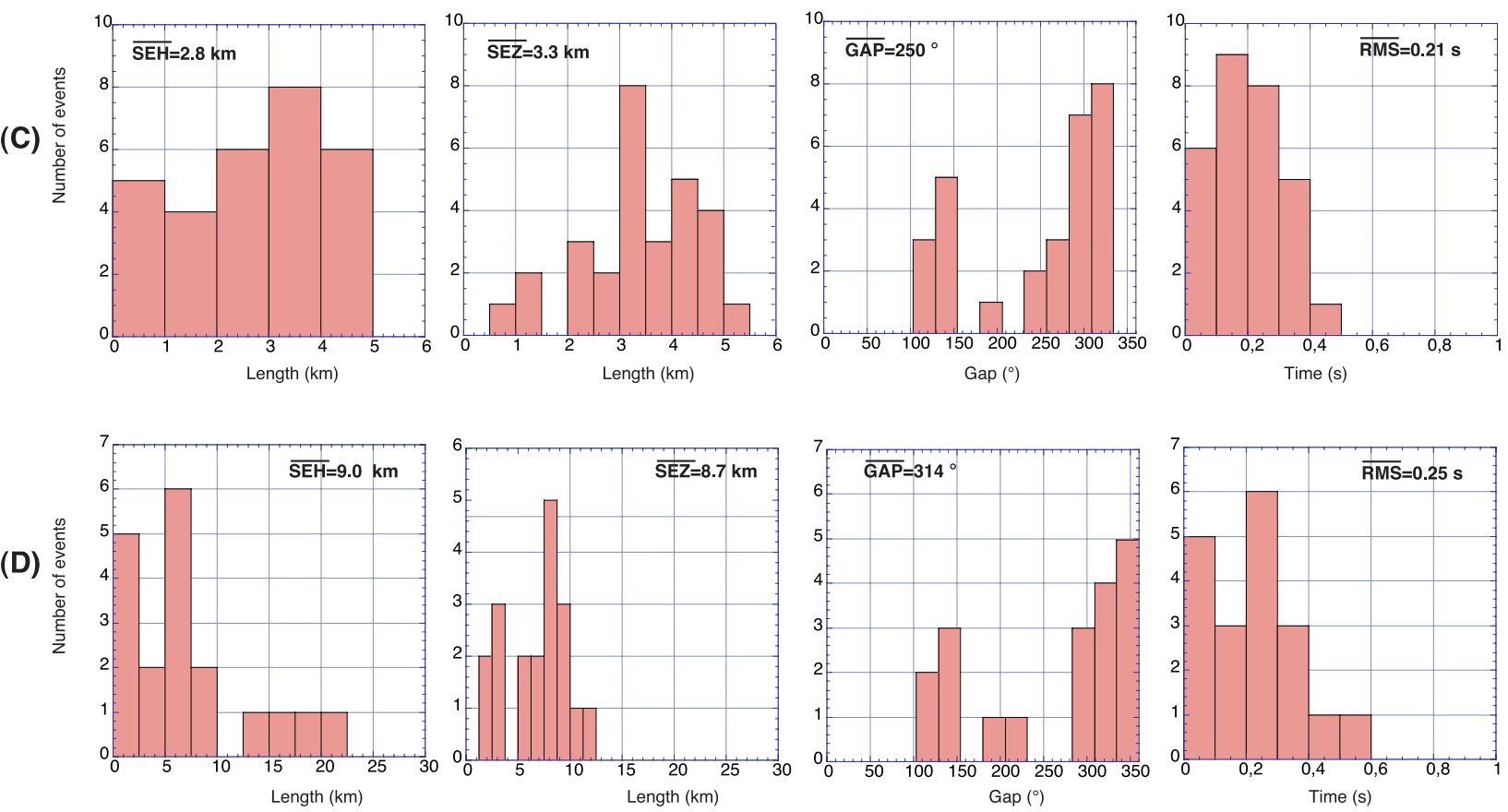

Statistics for all 111 events
q $\quad \# \quad \%$
18
B - 4541
C - 2926
D - $17 \quad 15$

$\overline{\mathrm{Npha}}=10$

$\overline{\mathrm{RMS}}=0.22 \mathrm{~s}$

Figure 13. Histograms of horizontal (SEH), vertical (SEZ), Gap and RMS for each class of hypocenters A, B, C, and D. Note that the RMS does not change significantly from class to class. 


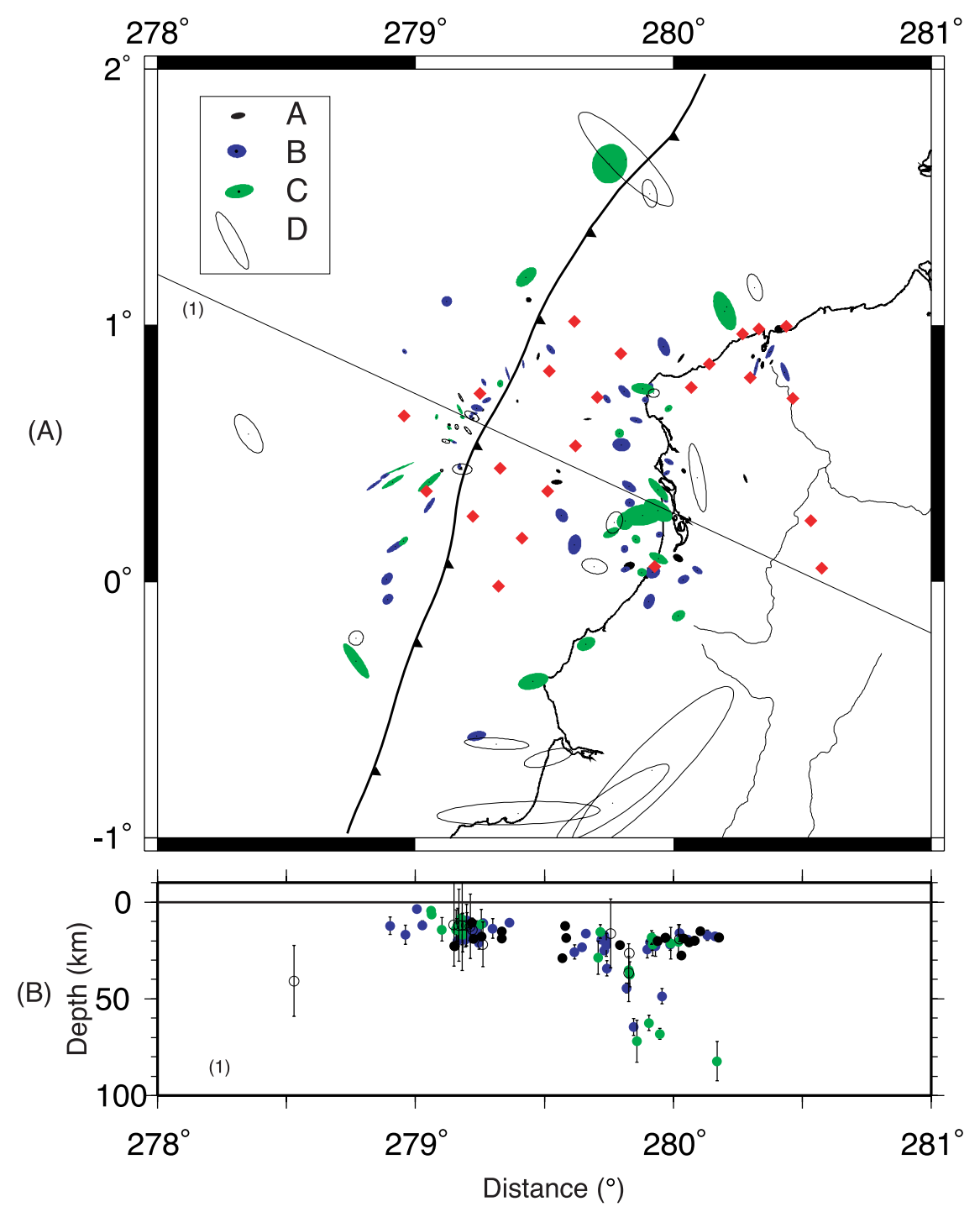

Figure 14. (a) Error ellipsoids map projection. Black symbols: quality A, blue symbols: quality B, green symbols: quality C, open symbols: quality D. Red diamonds are OBS and land stations. Thin black line shows trace of the projection plane on the surface. (b) Vertical error-bars superimposed on hypocenters projected onto the vertical plane 1.

Figure 15. (a) Map of the epicenters, with a quality color code: black dots: quality A, blue dots: quality B, green dots: quality C, open circles: quality D. Red diamonds are OBS and land stations. Thin black lines show traces of the projection planes 1 and 2 on the surface, the bracket on plane (1) shows width of the projection. (b) Cross-section in a NNE - SSW direction (vertical plane 2). (c) Cross-section in a WNW - ESE direction (vertical plane 1). This figure allows defining the Updip Limit (UdL) and the dip-angle of the seismogenic zone at $12 \mathrm{~km}$-depth and $10^{\circ}$ respectively. (d) Cross-section in a WNW - ESE direction (vertical plane 1) showing hypocenters from the permanent Ecuadorian seismic Network (yellow dots) superimposed with hypocenters from the CMT catalog (red dots). The cluster of earthquakes in the top-right of the figure is located below the Early Tertiary suture located on the western flank of the Western Cordillera of the Andes. (e) Cross-section in a WNW - ESE direction (vertical plane 1) showing hypocenters from our data set (black, blue, green dots and open circles) superimposed with hypocenters from the permanent Ecuadorian seismic Network Catalog (yellow dots) and the CMT catalog (red dots). The seismogenic zone is located at $20 \mathrm{~km}$-depth in the Esmeraldas area. The thick red line is a sketch of the contact zone between the Nazca and the South American plates. 
(A)

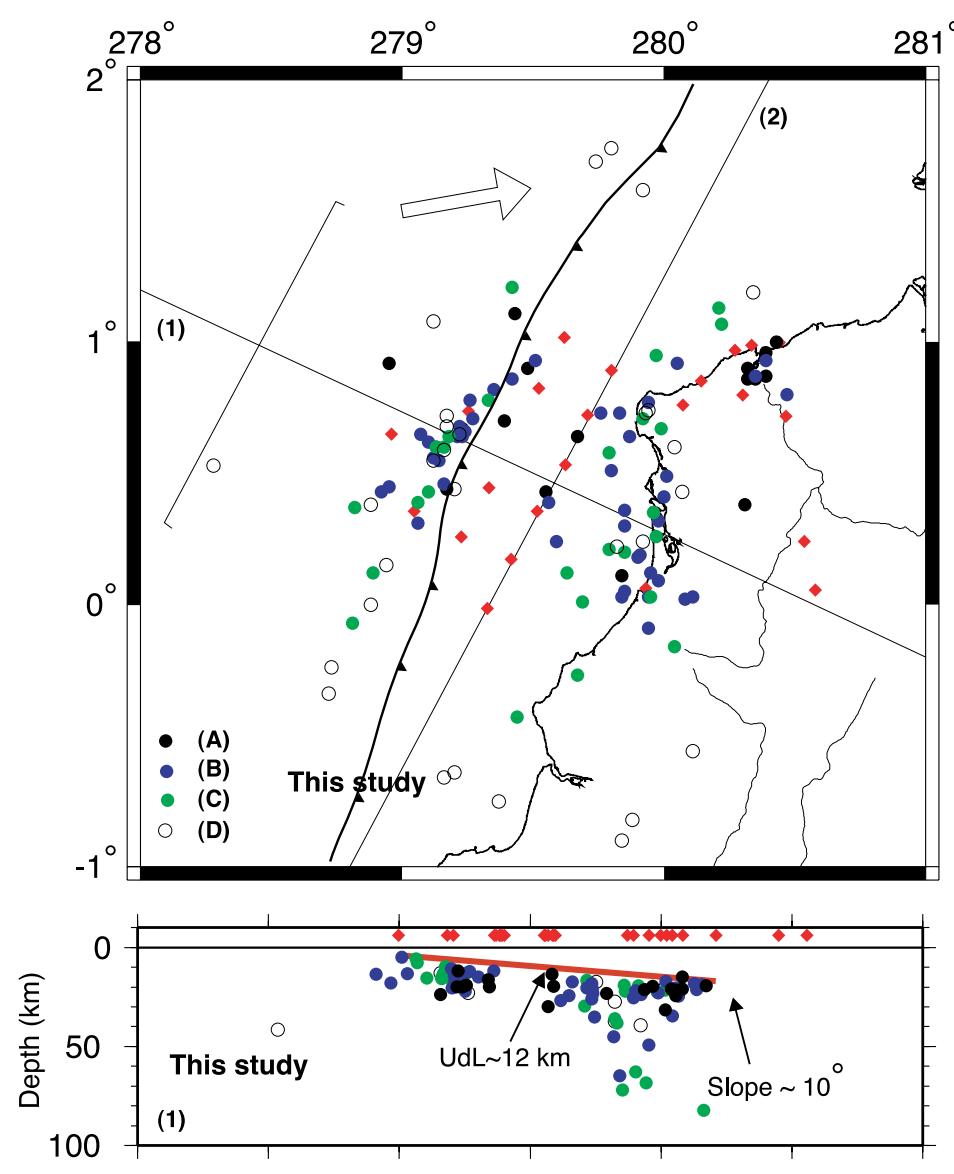

(B)

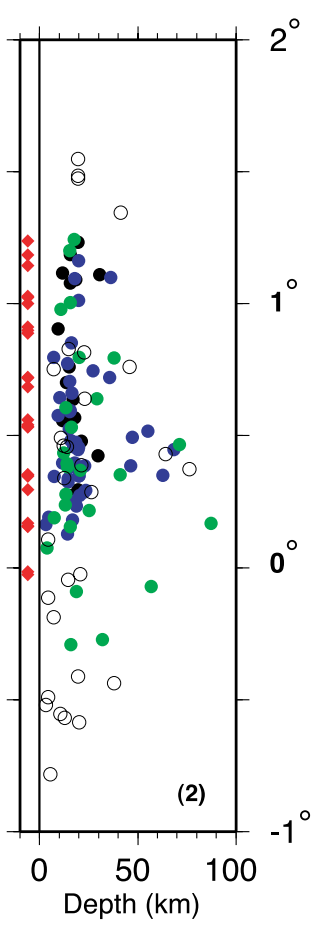

(C)

Depth (km)

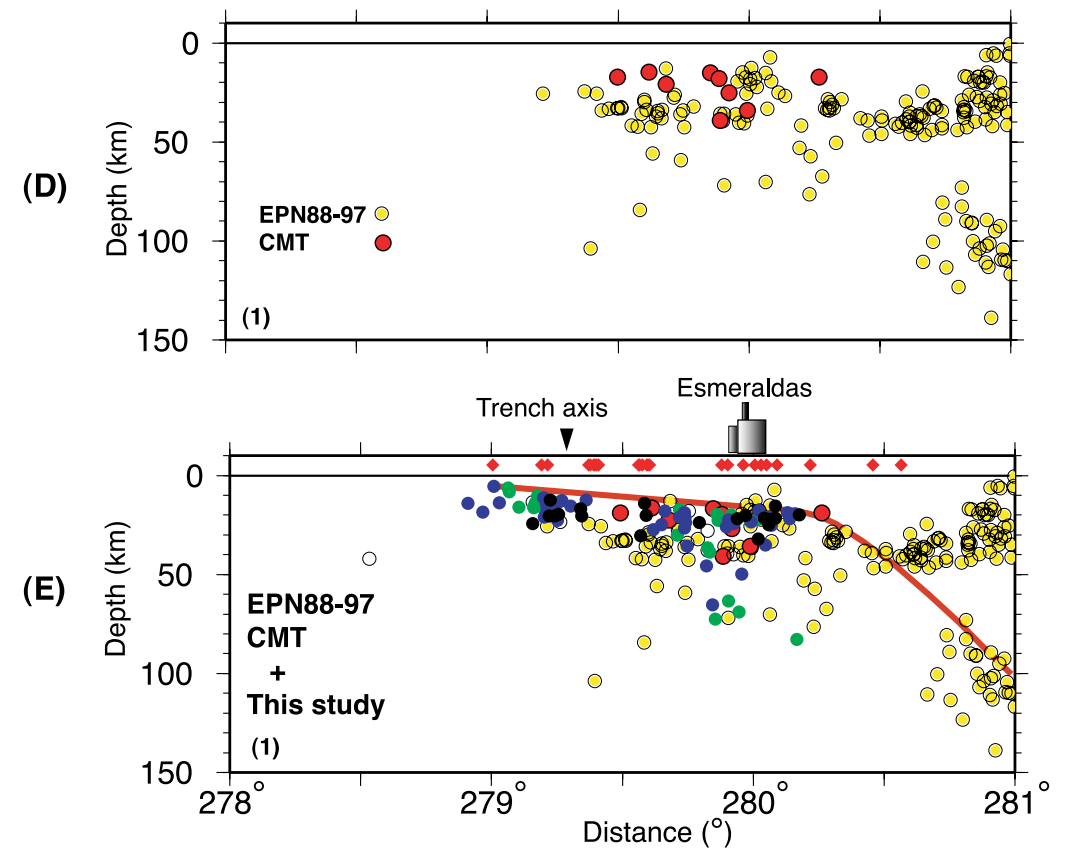

Figure 15. 

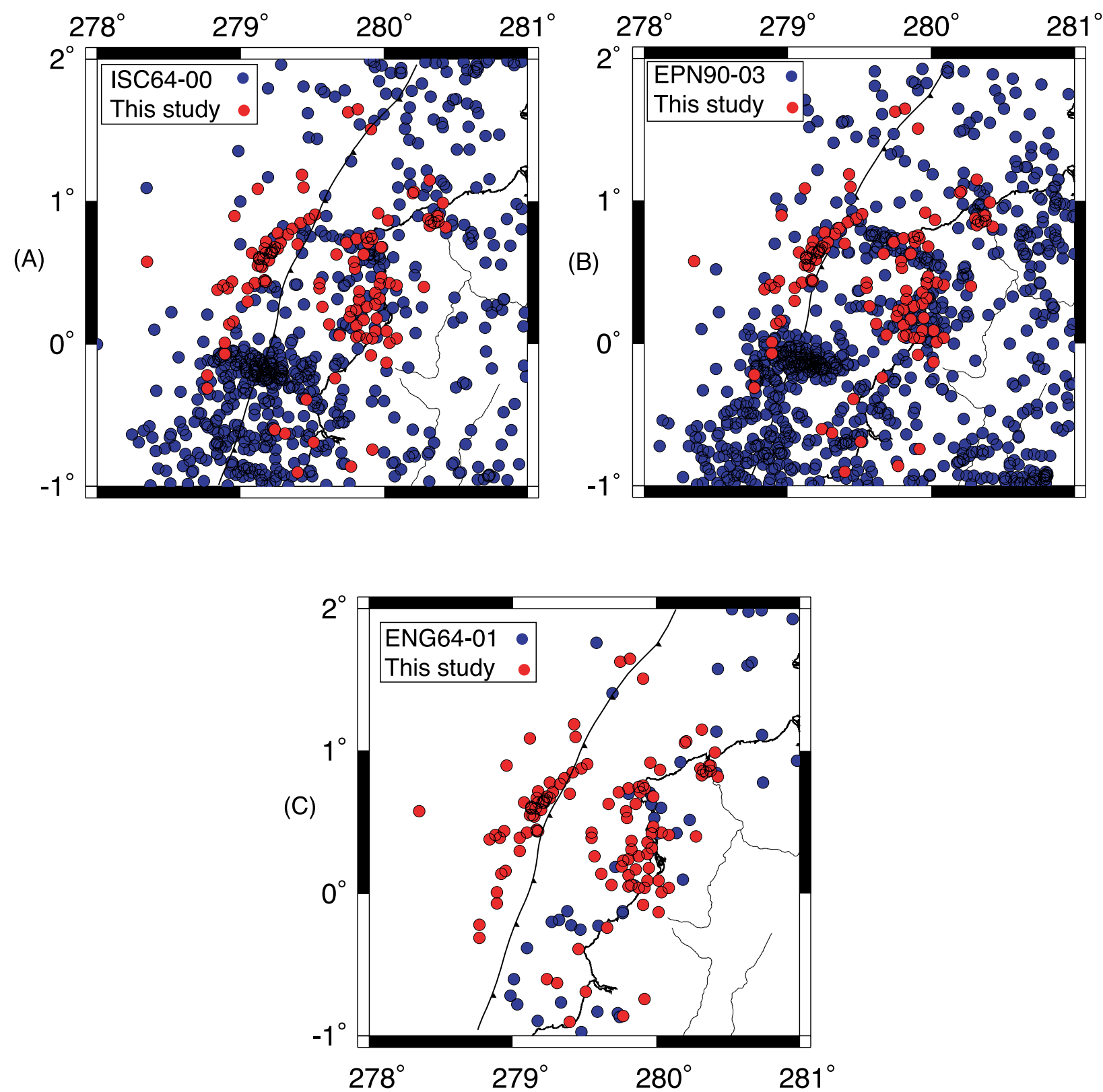

Figure 16. This study microearthquakes data set (red dots) superimposed with global and local seismicity as deduced from public earthquake catalogs (blue dots). Note that our data set is very representative, mainly along the coastline, of the epicentral distribution of the seismic activity reported by other catalogs. It also better defines the seismicity West of the trench whereas ISC and EPN report more diffuse seismicity. However, our hypocentral depth is better constrained. (a) International Seismological Center Catalog (ISC) for the time period 1964 to 2000 . All events of the catalog are plotted. (b) Permanent Ecuadorian Seismic Network Catalog for the time period 1990 to 2003. Only events having RMS $<1.5 \mathrm{~s}$ are plotted. (c) Engdahls Catalog for the time period 1964-2001. Only those events having good locations parameters are plotted (gap to teleseismic stations $<180^{\circ}$, good location in depth).

[47] 2. A relatively intense microearthquake activity is observed West of the trench (Figures $15 \mathrm{a}, 15 \mathrm{c}$ and $15 \mathrm{e}$ ). This activity extends from the surface to $\sim 25 \mathrm{~km}$-depth. Because of scarce data, it is not possible to calculate satisfactory focal mechanisms. Nevertheless, this observation could likely reflect oceanic plate stress regime while the oceanic plate bends before subducting, producing extensional 
(A)

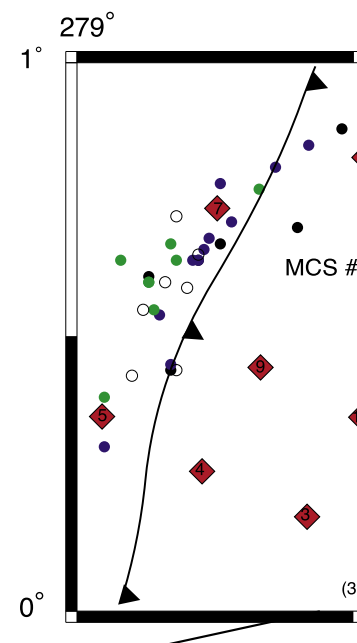

$280^{\circ}$

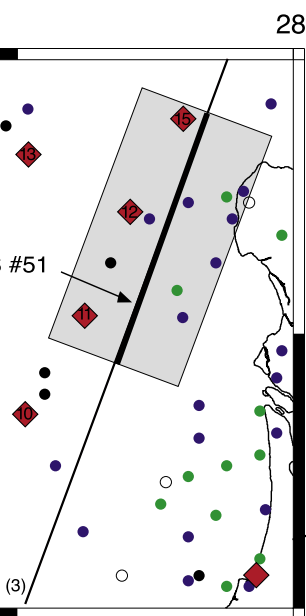

$+$

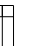

.<smiles>CCC</smiles>

(C)

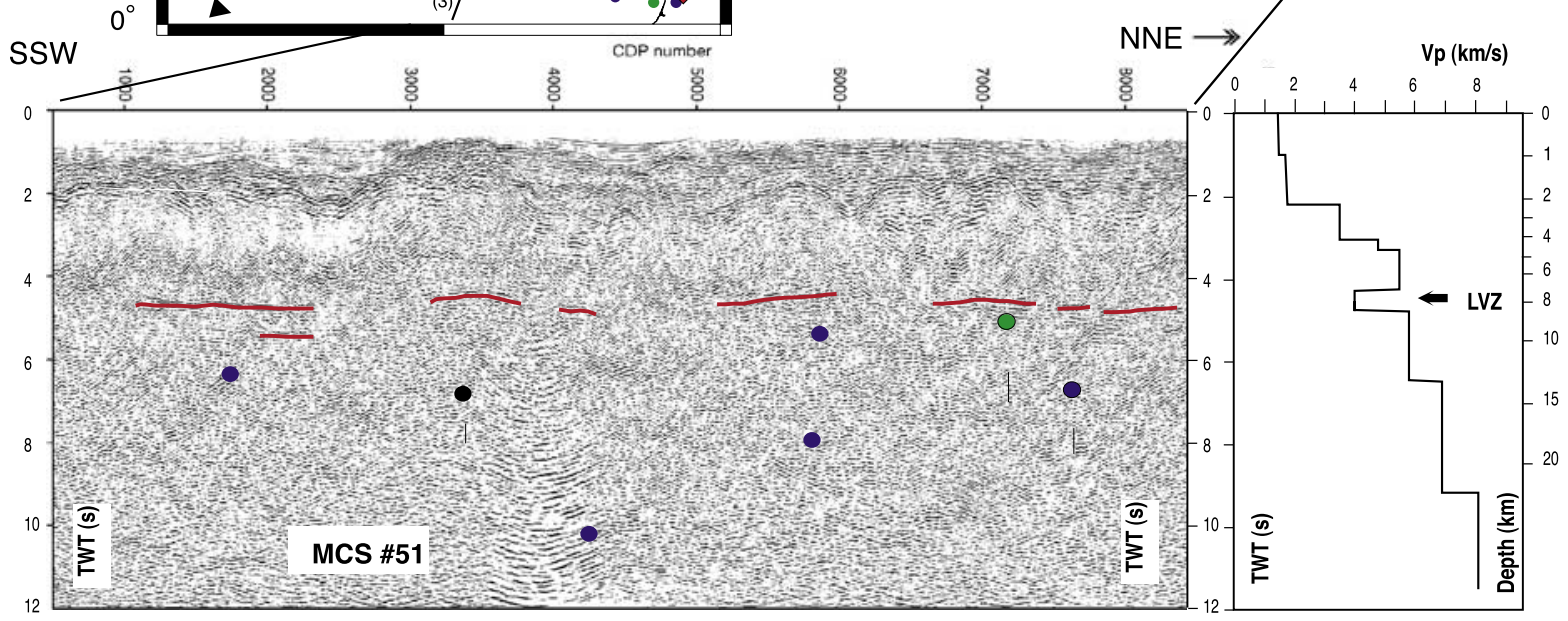

Figure 17. (a) Map showing the location of the MCS line 51 (thick black line) collected during the MCS-WAS experiment. Grey shaded area indicates the width of the projection presented on Figures $17 \mathrm{~b}$ and $17 \mathrm{c}$. (b) Projection of the shallowest $(0-25 \mathrm{~km})$ hypocenters along a vertical plane coinciding with MCS line 51. (c) Projection of the shallowest $(0-25 \mathrm{~km})$ hypocenters along the MCS line 51 . Vertical scale is Two-Way-Time (TWT) in seconds. The almost continuous reflector near $4.3 \mathrm{~s}$ TWT is highlighted in red. The right part of the figure represents the velocity model used here, after conversion in TWT vertical scale.

regime for its upper part and compressional regime for its lower part. The SSW-NNE trend of this oceanic crust epicentral distribution is in very good agreement with the trend of the normal faults detected on existing precise bathymetric maps.

[48] 3. Immediately East of the trench, the shallowest microseismic activity is found at $\sim 10 \mathrm{~km}-$ depth at a distance of $\sim 35 \mathrm{~km}$ from the trench. This observation shows that, East of the trench, the shallowest few kilometers of the contact zone between the two plates do not generate seismic activity. Therefore it is possible to define the UdL ( $\sim 12 \mathrm{~km}$-depth) of the seismogenic zone (Figure 15c). This observation if important for earthquake-induced tsunamis in the study area. As the UdL of the seismogenic zone does not reach the seafloor, it is likely that great earthquakes will not cause rupture shallower than $12 \mathrm{~km}$, and therefore would generate less energetic tsunamis than for rupture reaching the seafloor. Nevertheless, there are at least two reported historical tsunamis associated with the 1906 and the 1979 earthquakes. Our observation favors the hypothesis that the tsunami generation would be due to earthquake-triggered submarine landslides. Also, bathymetric data of the area suggest the presence of landslide features.

[49] Projection of the shallowest hypocenters on an existing MCS line 51 (Figure 17b) shows that the 
hypocenters are located immediately below an almost continuous reflector (Figure 17c-left), located between 4.2 and $4.5 \mathrm{~s}$ TWT. This reflector coincides with the LVZ as identified in the Manta area (Figure 17c-right). Again, this coincidence tends to justify the use of the Manta area structure in the Esmeraldas area. Therefore as it is the case in the Manta area, the velocity inversion can be interpreted as the signature of subducted oceanic sediments [Charvis et al., 2002; Gailler et al., 2003]. This observation shows that the local earthquakes occur within the subducted oceanic crust and, consequently, that the overlying plate does not exhibit seismic activity.

[50] 4. In this study, we located the seismicity recorded off Esmeraldas with a good resolution. Its spatial distribution shows that the depth of the shallowest hypocenters gradually increases eastward, from the UdL, as mentioned above, to $20 \mathrm{~km}$-depth for the easternmost loci, at a distance of $\sim 100 \mathrm{~km}$ East of the trench (Figure 15c). The dip angle is found to be $\sim 10^{\circ}$ between 0 and $100 \mathrm{~km}$ East of the trench. Eastward, the dip angle of the Benioff zone is $\sim 35^{\circ}$, as indicated by the hypocenters from the Ecuadorian Seismic Permanent Network catalog (Figures $15 \mathrm{~d}$ and 15e).

[51] This distribution defines an "aseismic wedge" with no intermediate-depth seismicity (i.e., $<15 \mathrm{~km}$ ). This observation is in good agreement with the outstanding lack of shallow low-level $\left(\mathrm{M}_{\mathrm{w}}<5\right)$ seismic activity of the coastal block, between the coastline and the western slope of the Andes, as mentioned by Guillier et al. [2001]. These considerations lead us to infer that the observed shallowest seismicity reflects the coupled zone between the two plates rather than the deformation of the upper plate. Consequently, we can deduce that the shallowest seismicity underlines the Seismogenic Zone. In addition to that, our data are in good agreement with previous observations, and therefore with the interpretation that the coastal block of Ecuador acts as an undeforming rigid body [Guillier et al., 2001].
[52] 5. Below the city of Esmeraldas, the shallowest microseismic activity is found at $\sim 20 \mathrm{~km}$ depth, $100 \mathrm{~km}$ East of the trench. This shallow depth of the seismogenic zone dramatically increases the seismic hazard of the area.

\section{Acknowledgments}

[53] We thank the IRD R/V Antéa crew, especially Captain H. Le Houarno, and Y. Hello, B. Guillier and F. Bondoux for their help in data acquisition, offshore and onshore. We also thank F. Kahn, IRD representative in Quito, for providing facilities for fieldwork, INOCAR (Instituto Oceanografico de la Armada) for providing their facilities in Guayaquil, and the IG-EPN (Instituto Geofisico de la Escuela Politecnica del Ecuador) for providing the regional earthquake database. Principal funding for this project was provided by IRD (Institut de Recherche pour le Développement, formerly ORSTOM). We also thank Drs. J. Kasahara, M. Semet, N. Bethoux and anonymous reviewers for their valuable reviews and suggestions to improve the quality of this paper. Contribution Géosciences Azur 603.

\section{References}

Ayres, A., and F. Theilen (1999), Relationship between P and $\mathrm{S}$ velocities and geological properties of near-surface sediments in the continental slope of the Barentz Sea, Geophys. Prospect., 47, 431-441.

Beck, S. L., and L. J. Ruff (1984), The rupture process of the great 1979 Colombia earthquake: Evidence for the asperity model, J. Geophys. Res., 89, 9281-9291.

Byrne, D. E., D. M. Davis, and L. R. Sykes (1998), Loci and maximum size of thrust earthquakes and the mechanics of the shallow region of subduction zones, Tectonics, 7, 833-857.

Calahorrano, A. (2001), Subduction de la ride de Carnégie sous la marge de l'Equateur, Rapport de DEA Dynamique de la Lithosphère, 32 pp., Univ. Pierre et Marie Curie, Paris.

Charvis, P., A. Gailler, V. Sallares, J. Y. Collot, D. Graindorge, A. Calahorrano, and R. Villamar (2002), Structure of the subduction channel at the Ecuador convergent margin from wide-angle seismic modeling and inversion, paper presented at Fifth International Symposium on Andean Geodynamics Meeting, IRD/Andean Comm. Of Int. Lithosphere Prog., Univ. Paul Sabatier, Toulouse.

Chatelain, J. L. (1978), Etude fine de la sismicité en zone de collision continentale à l'aide d'un réseau de stations portables: La région Hindu-Kush-Pamir, Thèse de 3 éme cycle, Univ. é de Grenoble, Grenoble, France.

Comte, D., and G. Suarez (1995), Stress distribution and geometry of the subducting Nazca plate in northern Chile using teleseismically recorded earthquakes, Geophys. J. Int., 122, 419-440

Engdahl, E. R., R. D. Van der Hilst, and R. P. Bukland (1998), Global teleseismic earthquake relocation with improved travel times and procedures for depth determination, Bull. Seismol. Soc. Am., 88, 722-743. 
Feininger, T., and M. K. Seguin (1983), Simple Bouguer gravity anomaly field and the inferred coastal structure of continental Ecuador, Geology, 11, 40-44.

Fujie, G., J. Kasahara, R. Hino, T. Sato, M. Shinohara, and K. Suyehiro (2002), A significant relation between seismic activities and reflection intensities in the Japan Trench region, Geophys. Res. Lett., 29(7), 1100, doi:10.1029/ 2001 GL013764.

Gailler, A. (2002), Structure de la zone de contact inter-plaques à partir des données de sismique de la campagne Sisteur (Equateur), Rapport de DEA Dynamique de la Lithosphère, 41 pp., Univ. Pierre et Marie Curie, Paris.

Gailler, A., P. Charvis, V. Sallares, J. Y. Collot, D. Graindorge, and A. Calahorrano (2003), Structure of the subduction channel at the Ecuador-Carnegie Ridge convergent margin from seismic modelling and inversion, paper presented at EGS-AGU-EUG Joint Assembly, Eur. Geophys. Soc., Nice.

Goosens, P. J., and W. I. Rose (1973), Chemical composition and age determination of tholeiitic rocks in the Basic Igneous Complex, Ecuador, Geol. Soc. Am. Bull., 84, $1043-1052$.

Guillier, B., J. L. Chatelain, E. Jaillard, H. Yepes, G. Poupinet, and J. F. Fells (2001), Seismological evidences on the geometry of the orogenic system in central-northern Ecuador (South-America), Geophys. Res. Lett., 28, 3749-3752.

Gutcher, M. A., J. Malavielle, S. Lallemand, and J.-Y. Collot (1999), Tectonic segmentation of the North Andean Margin: Impact of the Carnegie Ridge Collision, Earth Planet. Sci. Lett., 171, 335-341.

Gutcher, M. A., W. Sparkman, H. Bijwaard, and R. Engdhall (2000a), Geodynamics of a flat subduction:seismicity and tomographic constyraints from the andean margin, Tectonics, 19, 814-833.

Gutcher, M. A., R. Maury, J.-P. Eissen, and E. Bourdon (2000b), Can slab melting be caused by flat subduction?, Geology, 28, 535-538.

Hello, Y., P. Charvis, B. Pontoise, Y. Nakamura, and A. T. Chen (1992), Long range seismic refraction using digital OBS, Ann. Geophys., C51.

Herd, D. G., T. T. Youd, H. Meyer, J. L. Arango, W. J. Person, and C. Mendoza (1981), The Great Tumaco, Colombia Earthquake of 12 December 1979, Science, 211, 441-445.

Hino, R., S. Ito, H. Shiobara, H. Shimamura, T. Sato, T. Kanazawa, J. Kasahara, and A. Asegawa (2000), Aftershock distribution of the 1994 Shanriku-oki earthquake (Mw 7.7) revealed by ocean bottom seismographic observation, J. Geophys. Res., 105, 21,697-21,710.

Hughes, R. A., and L. F. Pilatasig (2002), Cretaceous and Tertiary terrane accretion in the Cordillera Occidental of the Andes of Ecuador, Tectonophysics, 345, 29-48.

Jaillard, E., S. Benitez, and G. Mascle (1997), Les déformations de la zone d'avant-arc sud-équatorienne en relation avec l'évolution géodynamique, Bull. Soc. Géol. France, $168,403-412$.

Kasahara, J., A. Kamimura, G. Fujie, and R. Hino (2001), Influence of water on earthquake generation along subduction zones, Bull. Earthquake Res. Inst., 76, 289-301.
Kelleher, J. (1972), Rupture zones of large South American earthquakes and some predictions, J. Geophys. Res., 77, 2087-2103.

Kellog, J., and V. Vega (1995), Tectonic development of Panama, Costa-Rica and the Colombian Andes: Constraints from Global Positioning System geodetic studies and gravity, in Geologic and Tectonic Development of the Carribean Plate Boundary in Southern Central America, edited by P. Mann, Geol. Soc. Am. Spec. Pap., 295, 7590.

Kissling, E., W. L. Ellsworth, D. Eberhart-Phillips, and U. Kradolfer (1995), Initial reference models in local earthquake tomography, J. Geophys. Res., 99, 19,63519,646 .

Lahr, J. C. (1999), Hypoellipse: A computer program for determining local earthquake hypocentral parameters, magnitude and first-motion pattern, U.S. Geol. Surv. Open File Rep., 99-23, 116 pp.

Lay, T., H. Kanamori, and L. Ruff (1982), The asperity model and the nature of large subduction zone earthquakes, Earthquake Prediction Res., 1, 3-71.

Lebrat, M., F. Mégard, C. Dupuy, and J. Dostal (1987), Geochemistry and tectonic setting of precollision Cretaceous and Paleogene volcanic rocks of Ecuador, Geol. Soc. Am. Bull., 99, 569-578.

Lee, W. H. K., and J. C. Lahr (1975), Hypo 71 (Revised): A computer program for determining hypocenter, magnitude and first motion pattern of local earthquakes, U.S. Geol. Surv. Open-File Rep., 75-311, 114 pp.

Legrand, D., A. Calahorrano, B. Guillier, L. Rivera, M. Ruiz, D. Villagomez, and H. Yepes (2002), Stress tensor analysis of the 1998-1999 tectonic swarm of northern Quito related to the volcanic swarm of Guagua Pichincha volcano, Ecuador, Tectonophysics, 344, 15-36.

Lonsdale, P. (1978), Ecuadorian Subduction System, Am. Assoc. Petrol. Geol. Bull., 62, 2454-2477.

Lonsdale, P., and K. D. Kiltgord (1978), Structure and tectonic history of the eastern Panama Basin, Geol. Soc. Am. Bull., 89, 981-999.

Luetgert, J. H. (1992), Interactive two-dimensional seismic raytracing for the Macintosh ${ }^{\mathrm{TM}}$, U.S. Geol. Surv. Open-File Rep., 92-356, 44 pp.

Mendoza, C., and J. Dewey (1984), Seismicity associated with the great Colombia-Ecuador earthquakes of 1942, 1958 and 1979, implication for barrier models of earthquake rupture, Bull. Seismol. Soc. Am., 74, 2, 577-593.

Nakamura, Y., and J. Garmany (1991), Development of upgraded ocean bottom seismograph, Tech. Rep., 111, 1-45, Univ. Tex., Inst. for Geophys., Austin.

Nakamura, Y., P. L. Donoho, P. H. Roper, and P. M. McPherson (1987), Large offset seismic surveying using ocean bottom seismographs and air-guns: Instrumentation and field technique, Geophysics, 52, 1601-1611.

Nishenko, S. P. (1991), Circum-Pacific seismic potential 1989-1999, Pure Appl. Geophys., 135, 169-259.

Pennington, W. D. (1981), Subduction of the eastern Panama basin and seismotectonics of northwestern South America, J. Geophys. Res., 86, 10,753-10,770. 
Pontoise, B., and Y. Hello (2002), Monochromatic infra-sound waves recorded offshore Ecuador: Possible evidence of methane release, Terra Nova, 14, 1-11.

Prévôt, R., J.-L. Chatelain, B. Guillier, and H. Yepes (1996), Tomographie desAndes Equatoriennes: Évidence d'une continuité des Andes Centrales, C. R. Acad. Sci. Paris, 323, $833-840$.

Roperch, P., F. Mégard, C. Laj, T. Mourier, T. Clubeand, and C. Noblet (1987), Rotated oceanic blocks in western Ecuador, Geophys. Res. Lett., 14, 558-561.

Sallarès, V., P. Charvis, E. Flueh, J. Bialas, and C. Walther (2002), Wide-Angle Seismic Constraints on the Evolution of Galapagos Hot spot-Cocos - Nazca Spreading Center Interaction, paper presented at the EGS General Assembly, Eur. Geophys. Soc., Nice.

Schreiner, A. E., L. M. Dorman, and L. D. Bibee (1991), Shear wave velocity structure from interface waves at two deep water sites in the Pacific Ocean, in Shear Waves in Marine Sediments, edited by J. M. Hoven, M. D. Richardsonand, and R. D. Stoll, pp. 231-238, Kluwer Acad., Norwell, Mass.

Swenson, J. L., and S. L. Beck (1996), Historical 1942 Ecuador and 1942 Peru subduction earthquakes, and eartquakes cycles along Colombia-Ecuador and Peru subduction segments, Pure Appl. Geophys., 146, 67-101.
Sykes, L. R. (1971), Aftershock zones of great earthquakes, seimicity gaps, and earthquake prediction for Alaska and the Aleutians, J. Geophys. Res., 76, 8021-8041.

Taboada, A., L. A. Rivera, A. Fuenzanilla, A. Cisternas, H. Philip, H. Bijwaard, J. Olaya, and C. Rivera (2000), Geodynamics of the Northern Andes: Subductions and intracontinental deformation (Colombia), Tectonics, 19, 787-813.

Tichelaar, B. W., and L. Ruff (1991), Seismic coupling along the Chilean subduction zones, J. Geophys. Res., 96, 11,97712,022 .

Tichelaar, B. W., and L. Ruff (1993), Depth of seismic coupling alond subduction zones, J. Geophys. Res., 98, $2017-$ 2038.

Tsuru, T., J. O. Park, N. Takahashi, S. Kodaira, Y. Kido, Y. Kaneda, and Y. Kono (2000), Tectonic features of the Japan Trench convergent margin off Sanriku, northeastern Japan, revealed by multichannel seismic reflection data, J. Geophys. Res., 105, 16,403-16,413.

Vrolijk, P. (1990), On the mechanical role of smectite in subduction zones, Geology, 18, 703-707.

White, R. S., D. Mc Kenzie, and R. K. O’Nions (1992), Oceanic crustal thickness from seismic measurements and rare earth element inversions, J. Geophys. Res., 97, $19,683-19,715$. 